\title{
9.0 APPENDICES
}

9A - Descriptions of Plant Associations on the NTS

9B - Root Observations in Pit 8 at Area 5 RWMS 
THIS PAGE INTENTIONALLY LEFT BLANK 


\section{APPENDIX 9A \\ Descriptions of Plant Associations on the NTS \\ (From Ostler et al., 2000)}

The following pages provide descriptions of plant associations that are found in the vicinity of Area 3 and Area 5 RWMSs. They provide general descriptions of the vegetation, its distribution across the Nevada Test Site, and other site conditions correlated with these plant associations. More detailed descriptions of these plant associations and vegetation are provided by Ostler et al. (2000). 


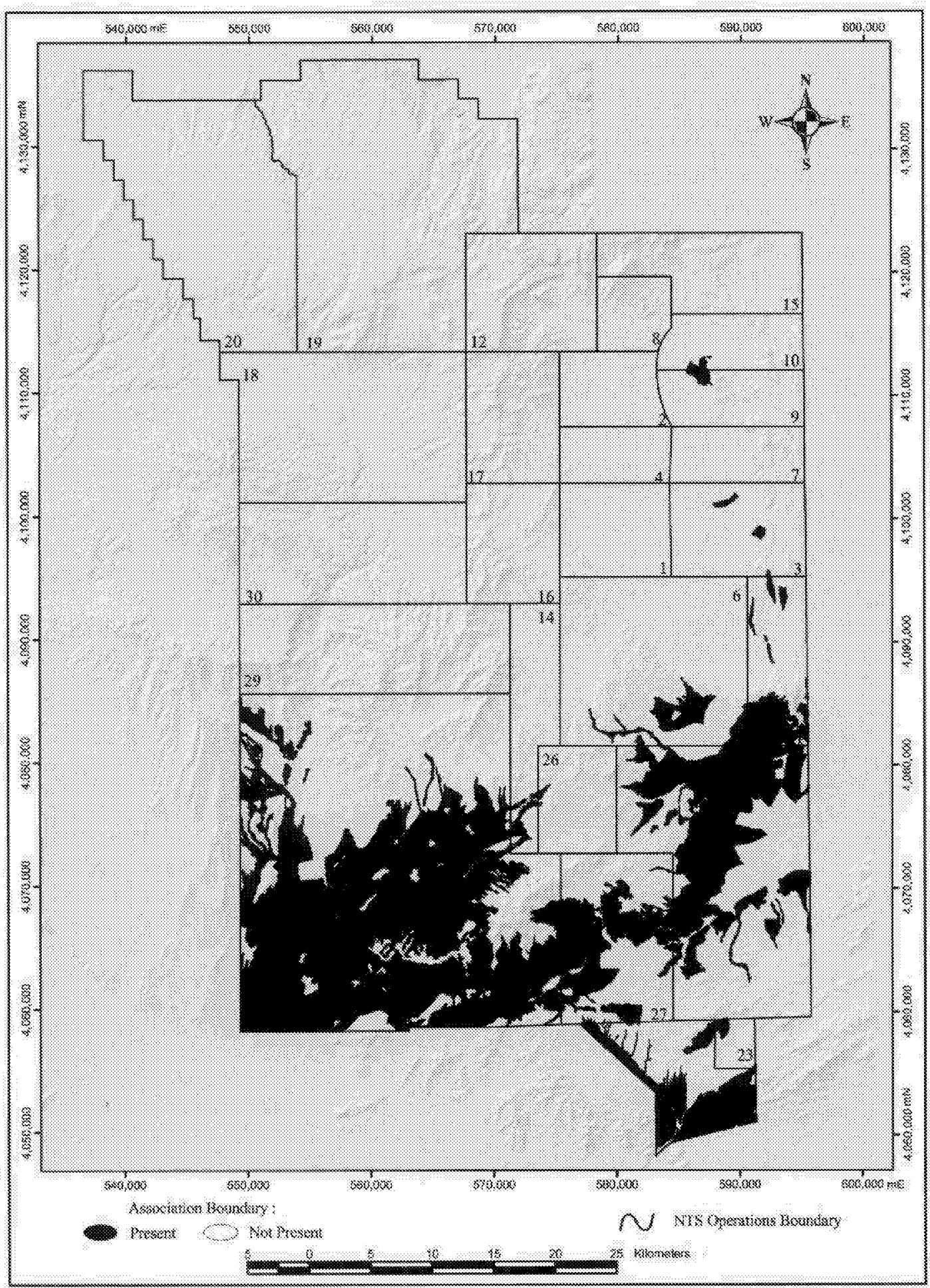

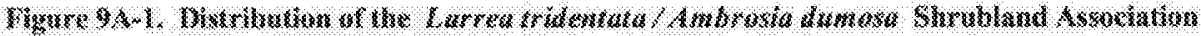

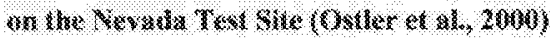




\section{A-1.0 Larrea tridentata/Ambrosia dumosa Shrubland}

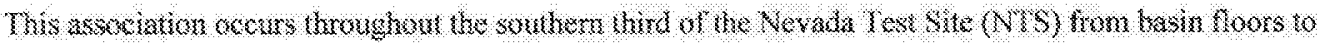

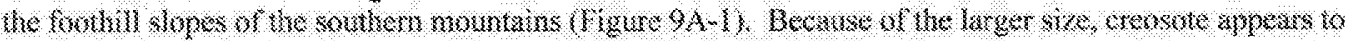

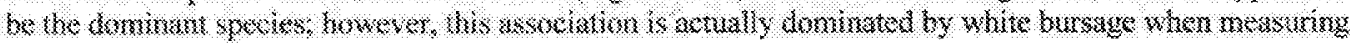

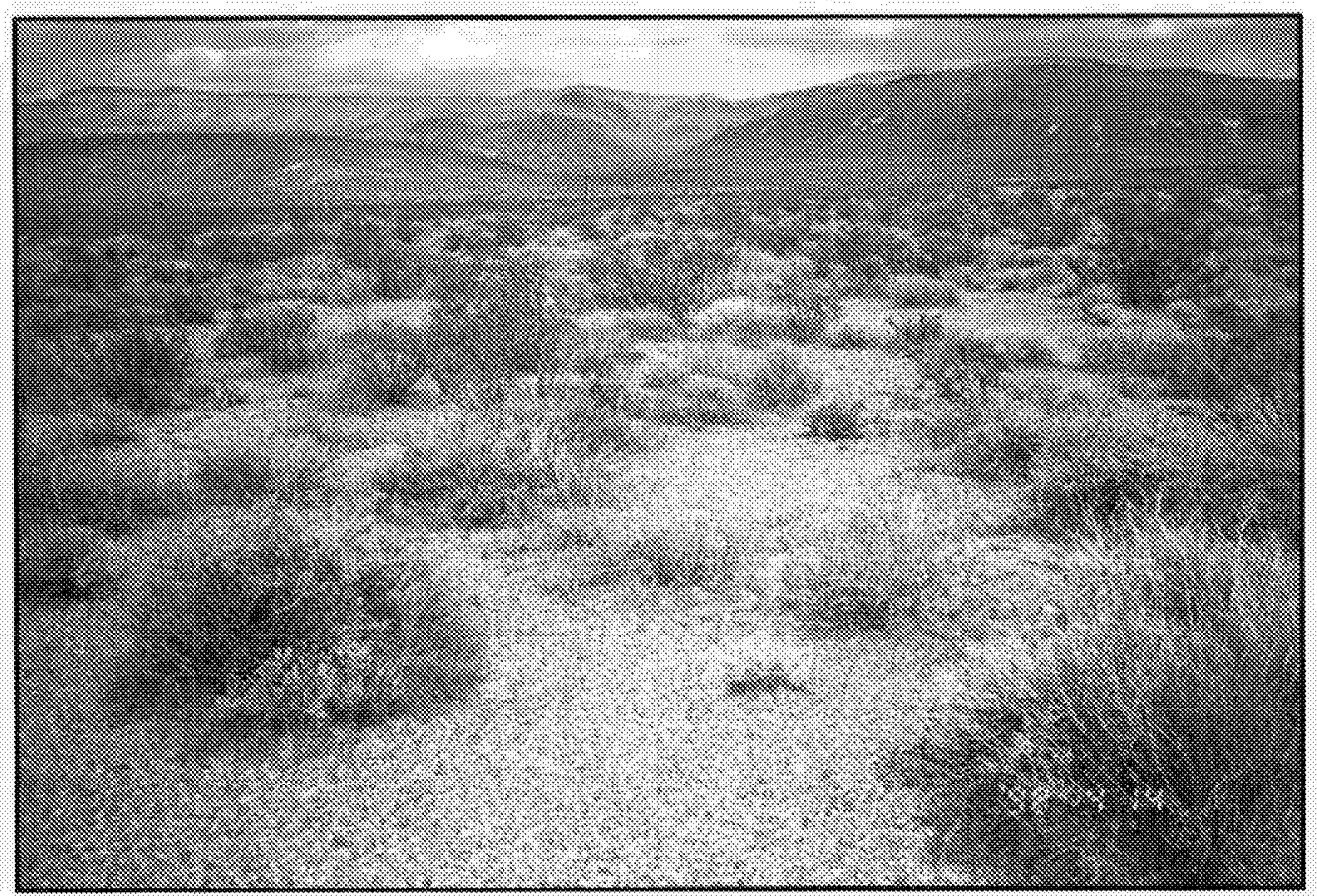

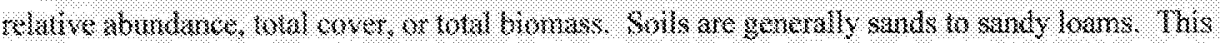

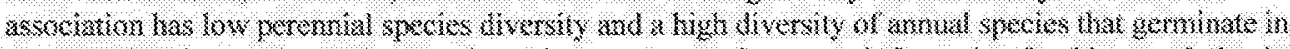

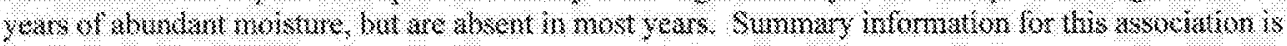

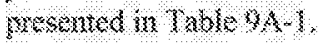

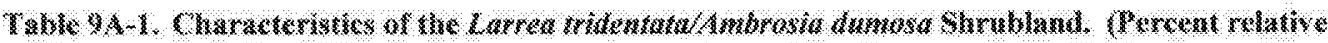

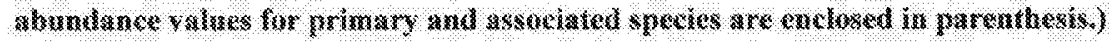

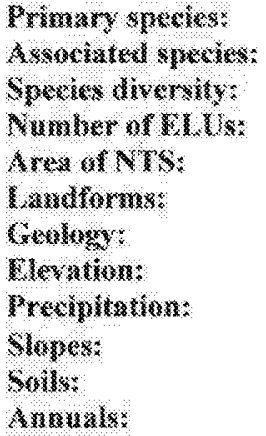

Whux bursaze $(43 \%)$, creosute bask $(13 \%)$

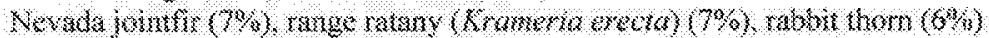

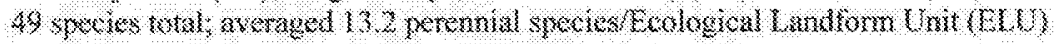
287

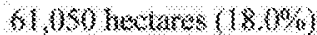

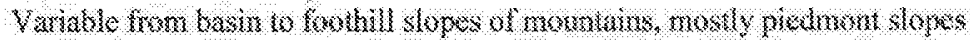

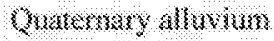

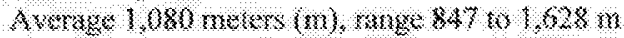

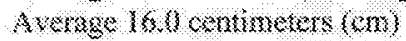

Arewage 5. ? , range 1 16 $42^{\circ}$

srimarly swmil no sandy lwan

bery but to moderate 


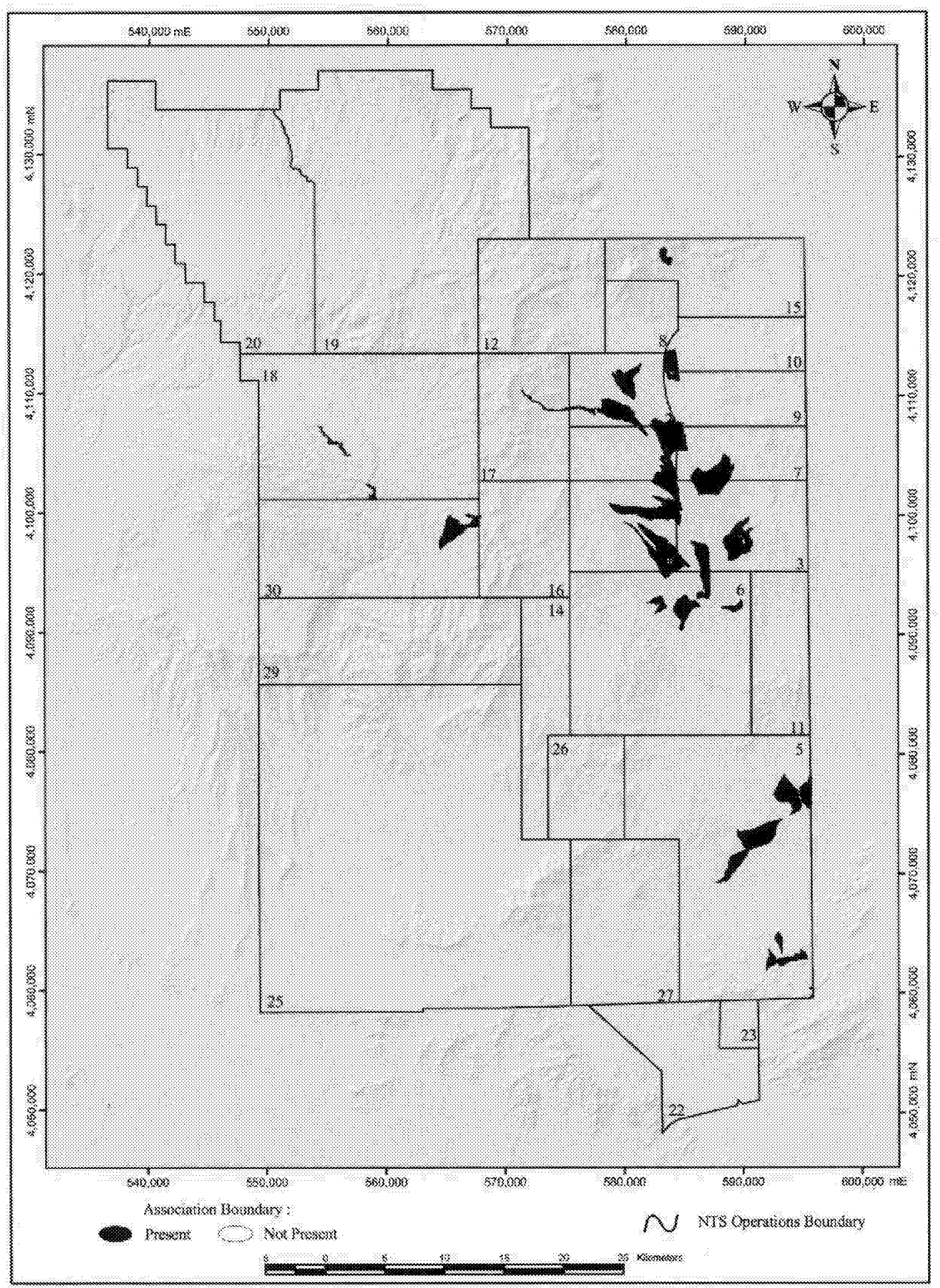

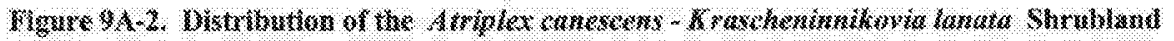

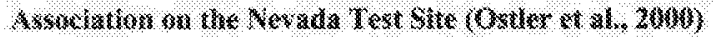




\section{A-2.0 Atriplex canescens-Krascheninnikovia lanata Shrubland}

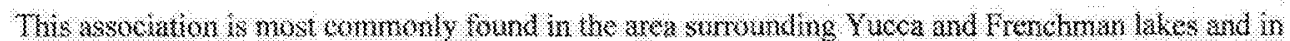

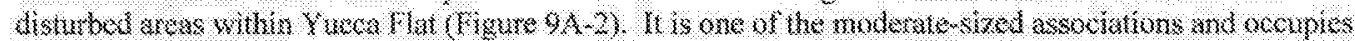

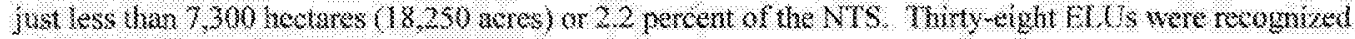

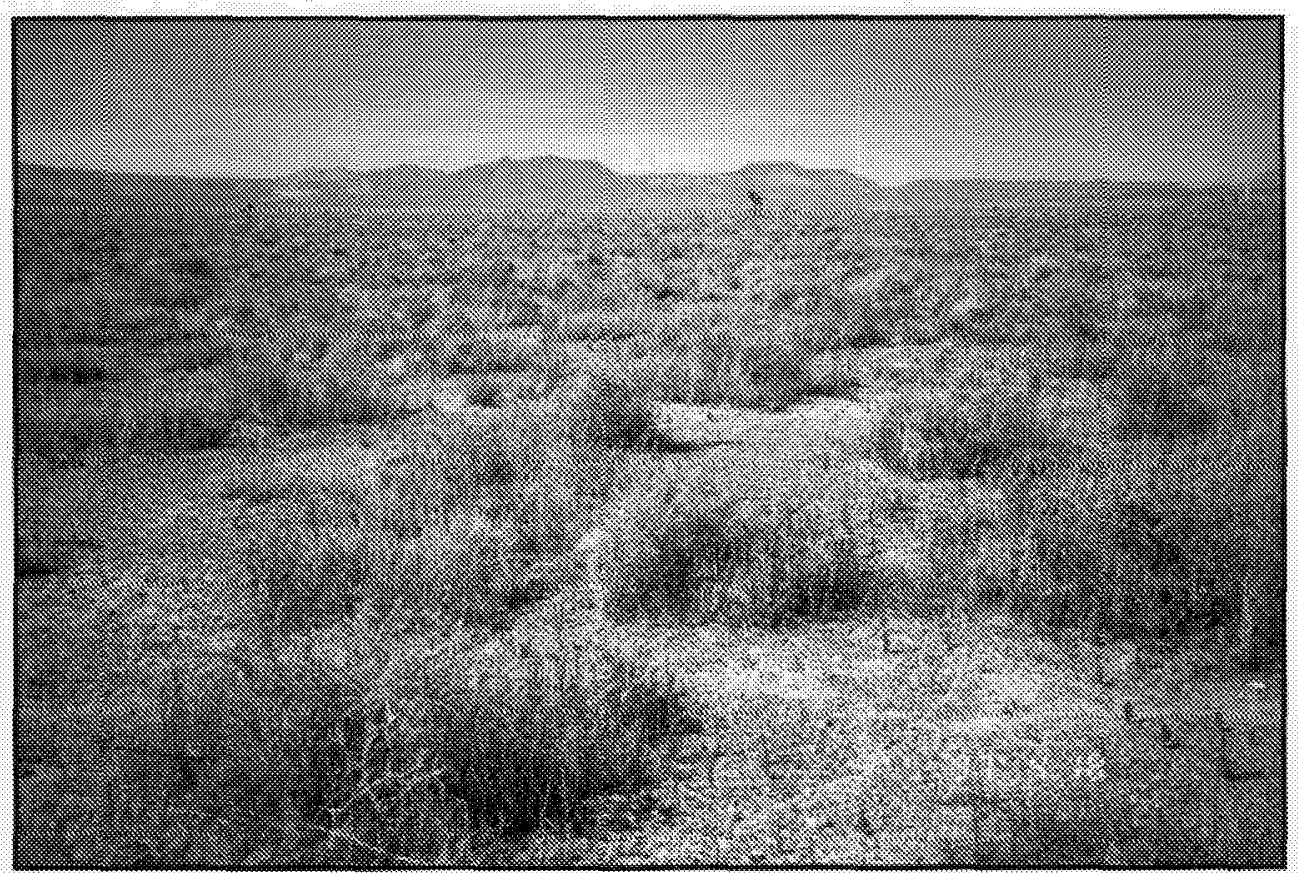

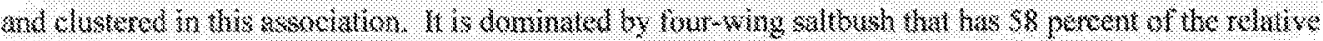

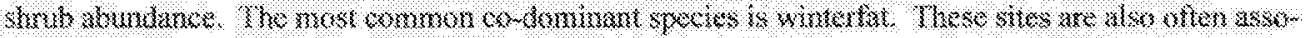

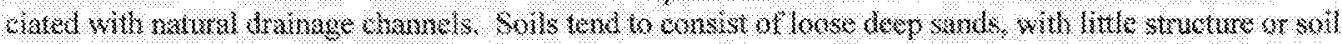

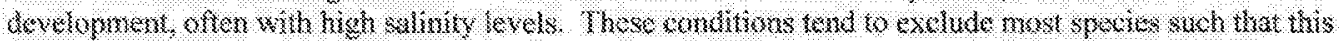

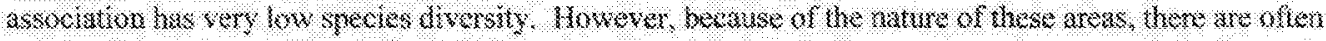

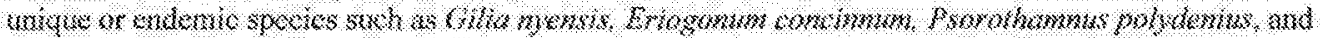

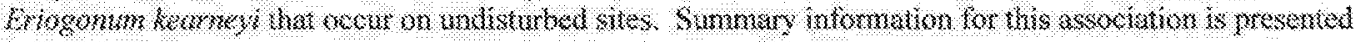

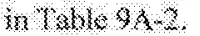

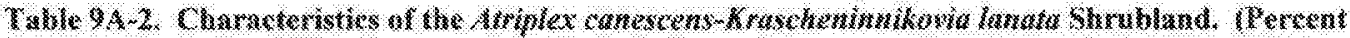

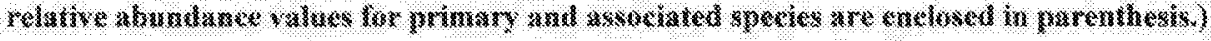

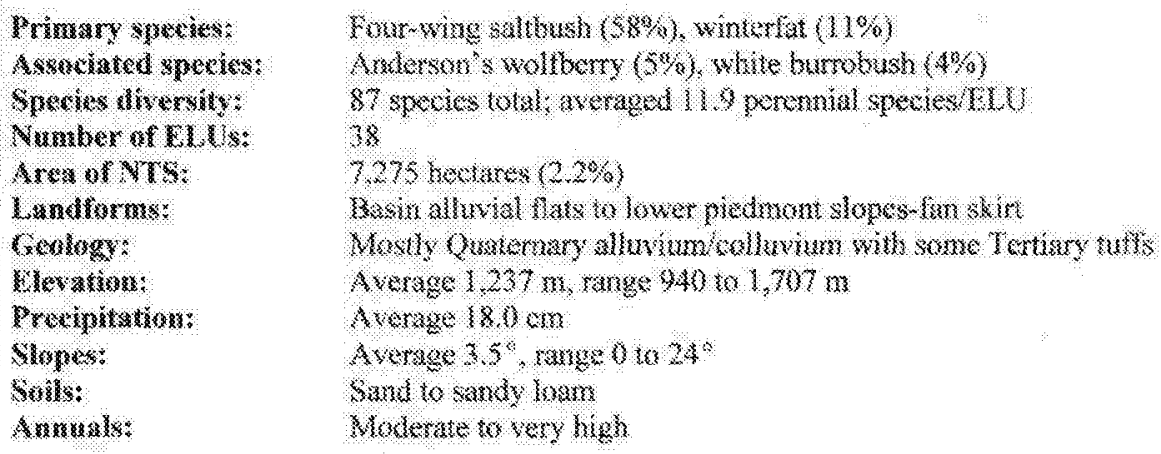




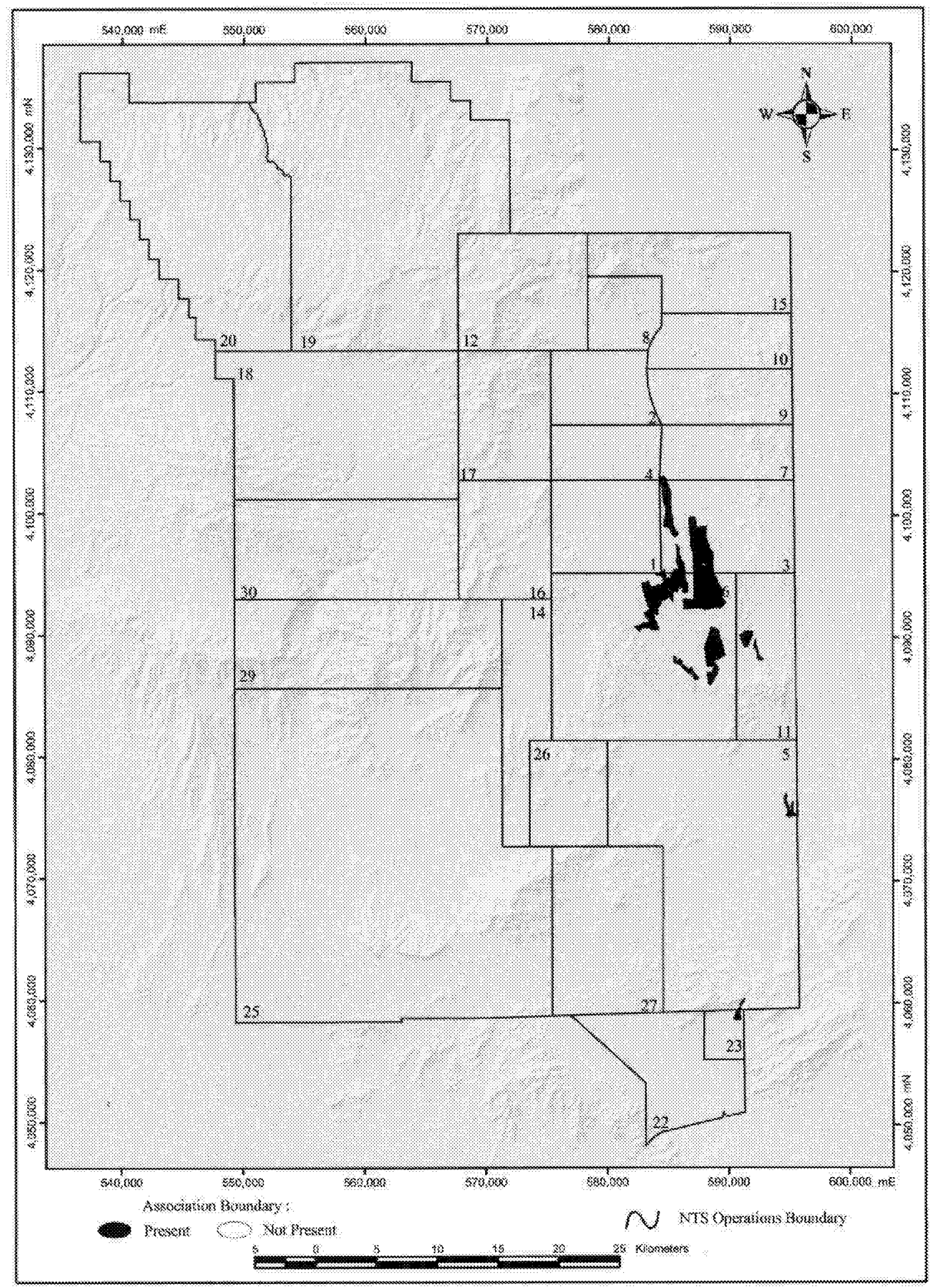

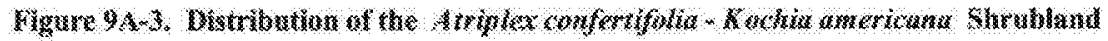

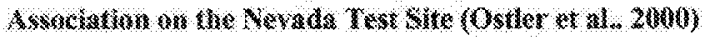




\section{A-3.0 Atriplex confertifolia-Kochia americana Shrubland}

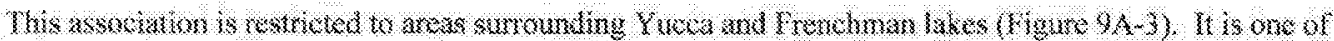

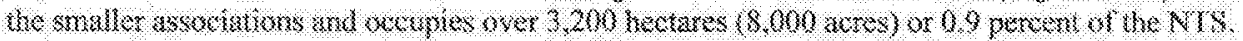

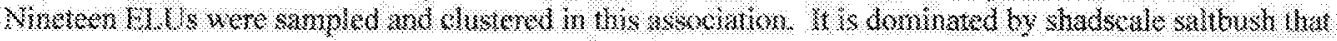

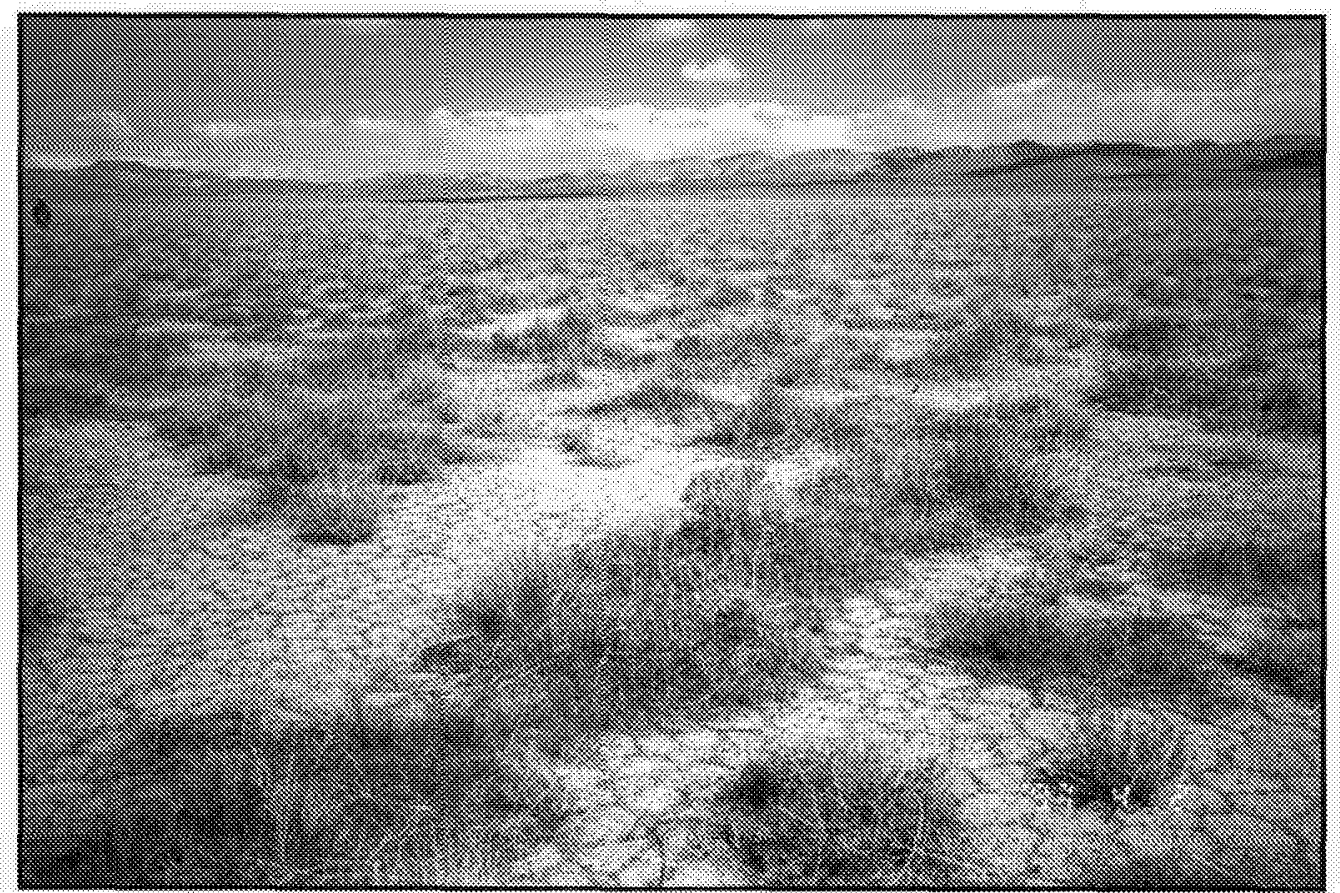

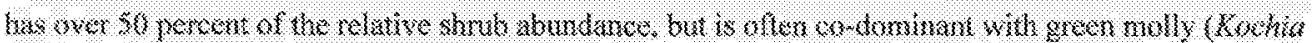

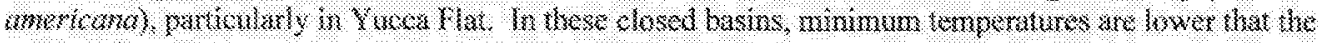

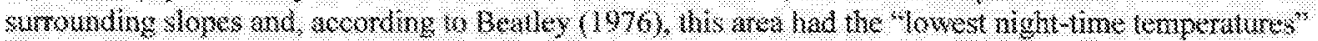

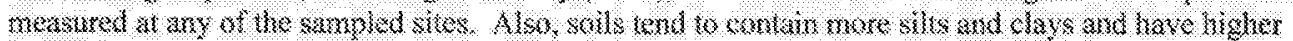

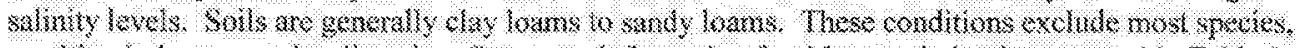

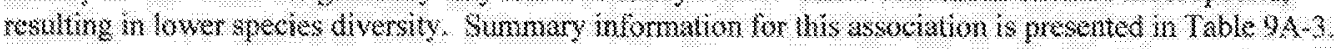

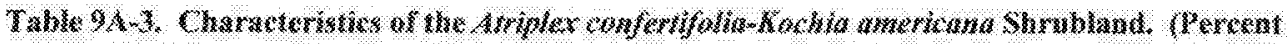

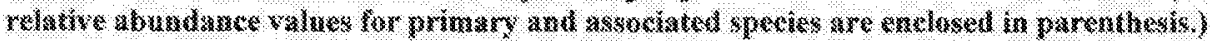

\section{Prims:ay speese:} Astaktated speerits:

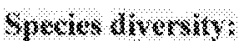

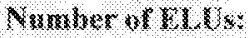
Aren ar WT: Lamullorm:

Crevilogy:

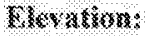

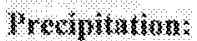

Sagras:

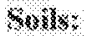

Ausmessebs:

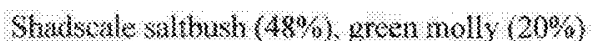

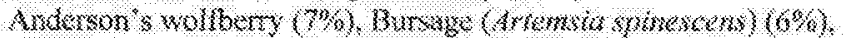
spitiv menouna $(3 \%)$, wintertist $(5 \%)$

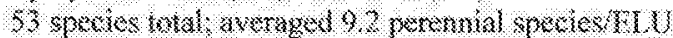
14

$321\}$ hectares $(00 \%)$

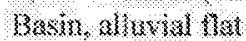

Quaksmary akluwitum

Average, $208 \mathrm{~m}$, range 940 60 $1382 \mathrm{~m}$

Average $7,6 \mathrm{~cm}$

Arcraze $23^{\circ}$, ramge 61020

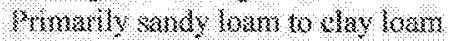

Low wo mouserise 


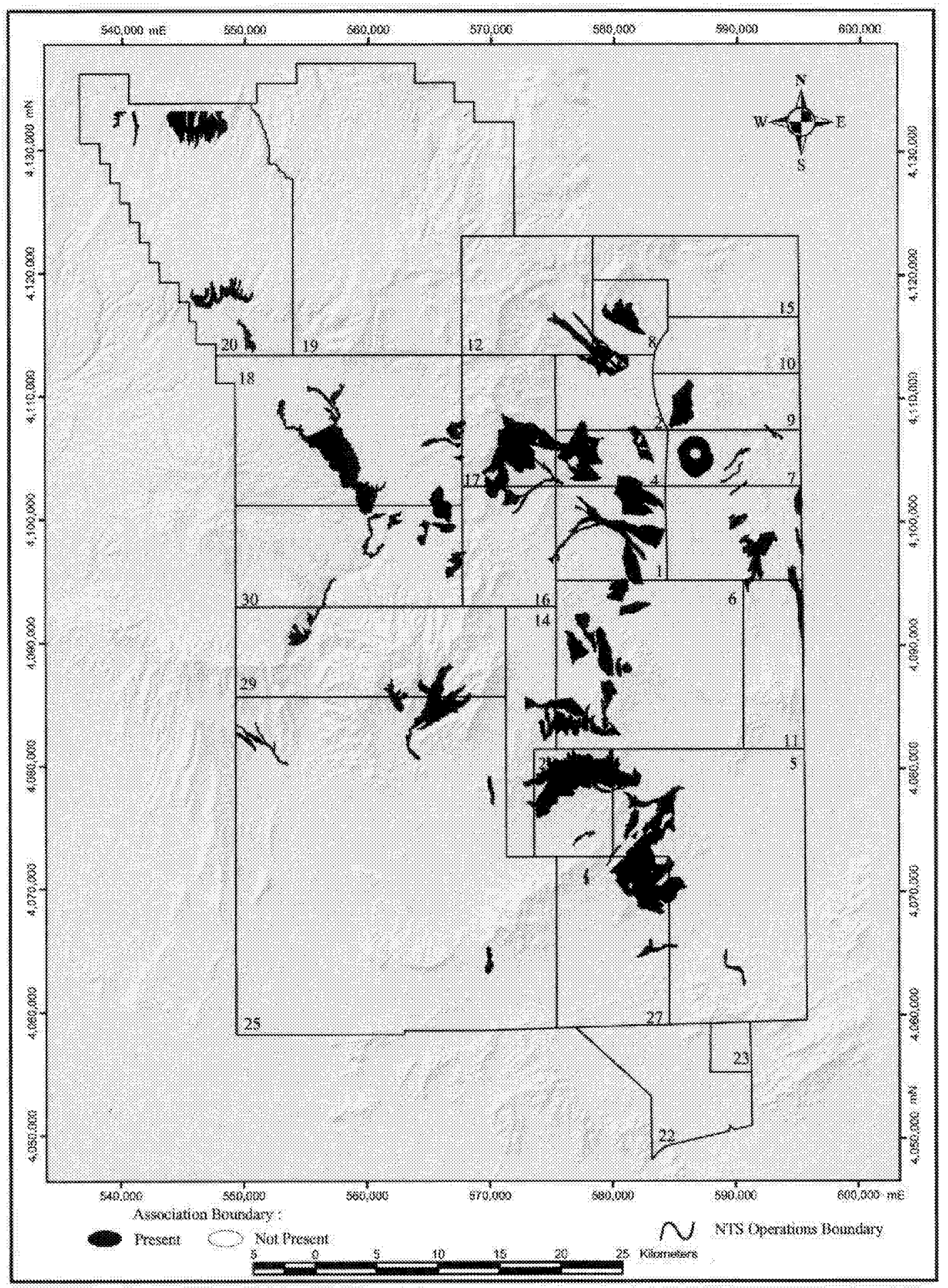

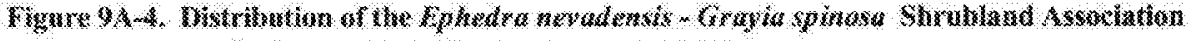

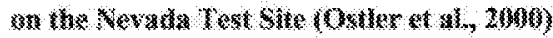




\section{A-4.0 Ephedra nevadensis-Grayia spinosa Shrubland}

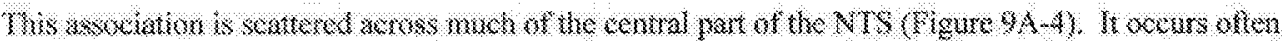

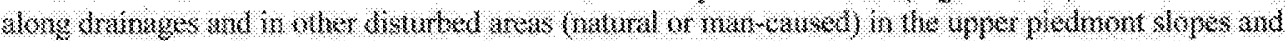

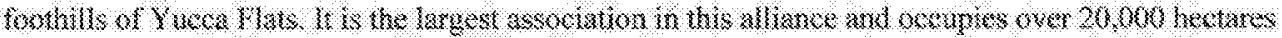

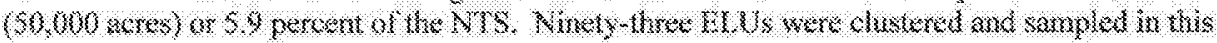

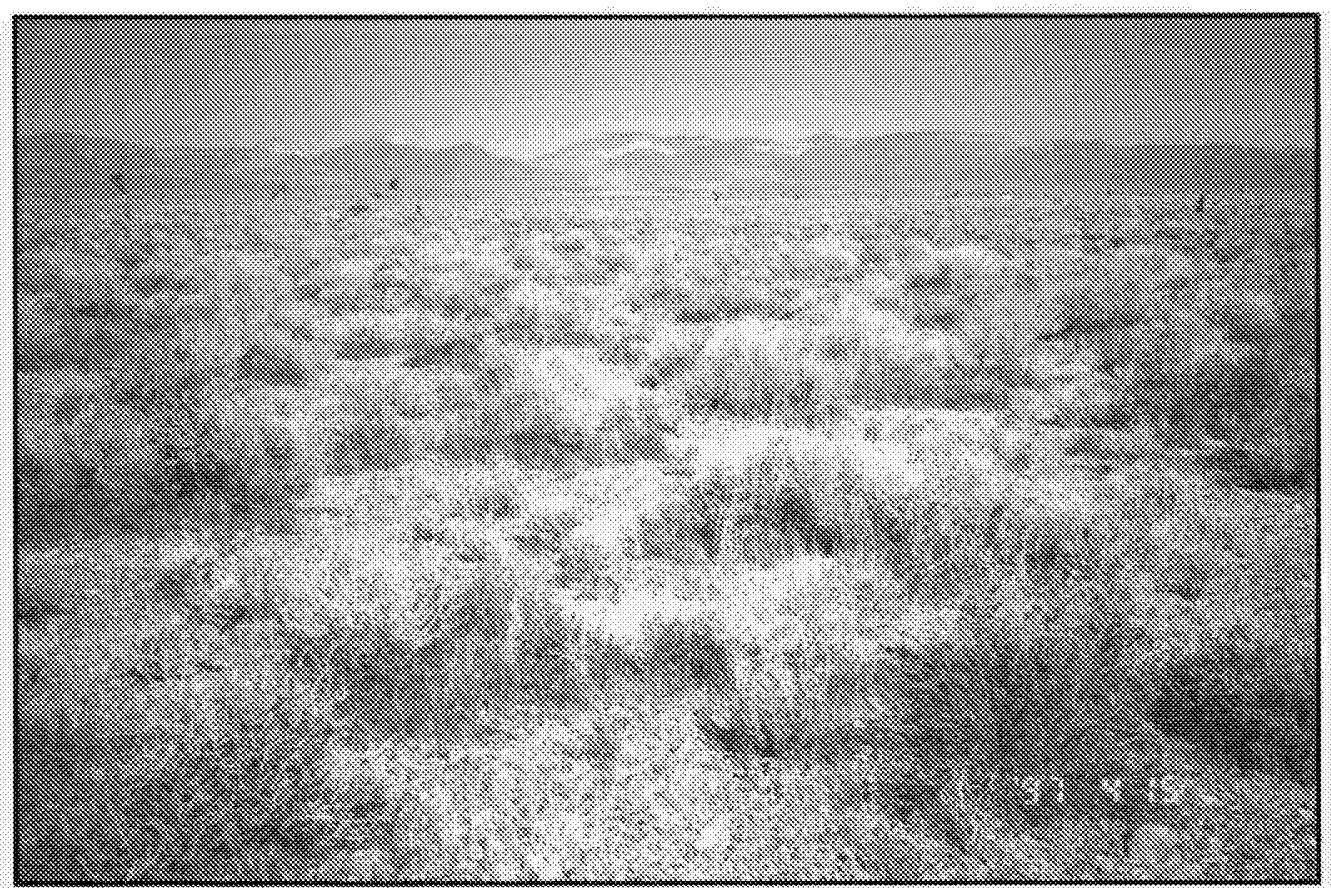

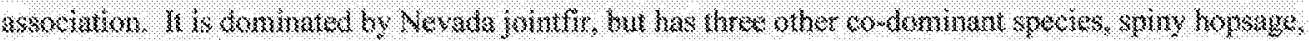

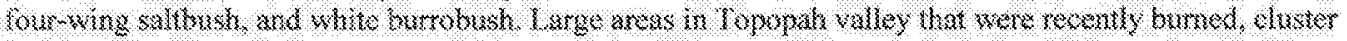

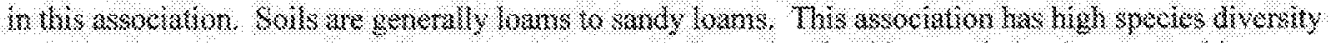

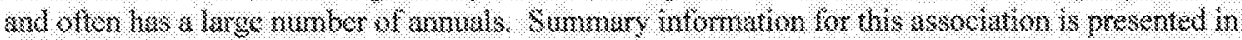
rate $9 \mathrm{k}$ a

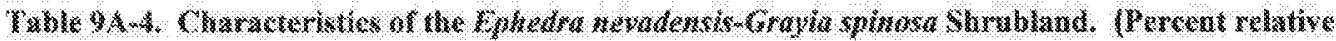

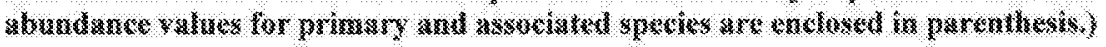

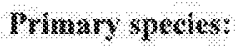
Axsotiated species:

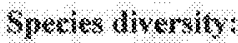

Jumber of EUU:

Aras of NTS:

I.amolorma:

Geology:

Wevation:

Preximitakinas:

Sloges:

Salk:

Amezzals:

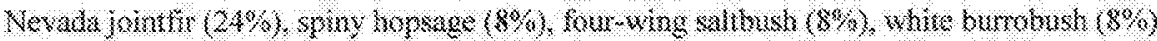

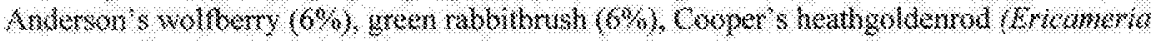
compreri) $\left(5^{*} \%\right)$, blakkmash $(4 \%)$

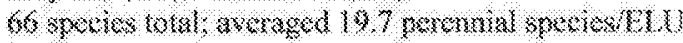

\section{9}

20,067 hectares $(50 \%)$

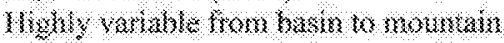

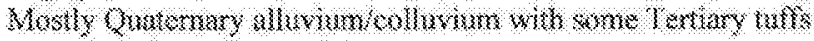

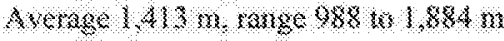

A trome $20.2 \mathrm{om}$

A wermye $88^{\circ}$, range $/$ क $70^{\circ}$

Prumary loamy sand to lomm

Nordante to kery higls 


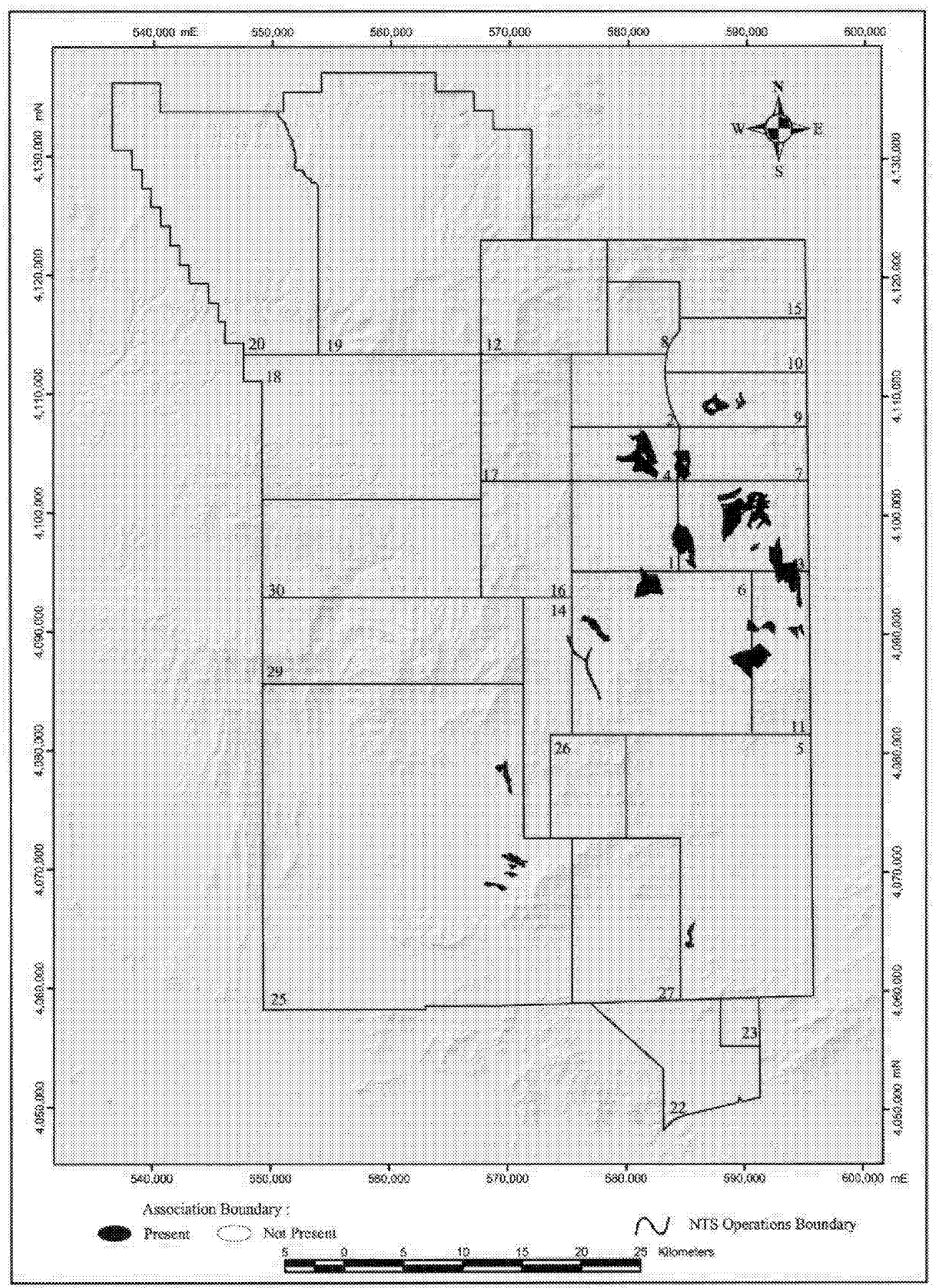

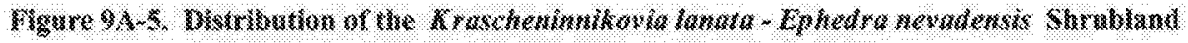

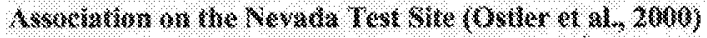




\section{A-5.0 Krascheninnikovia lanata-Ephedra nevadensis Shrubland}

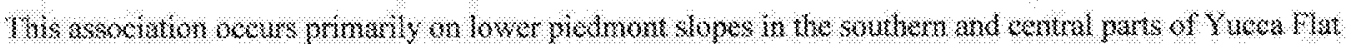

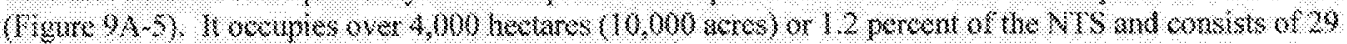

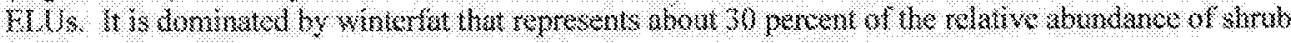

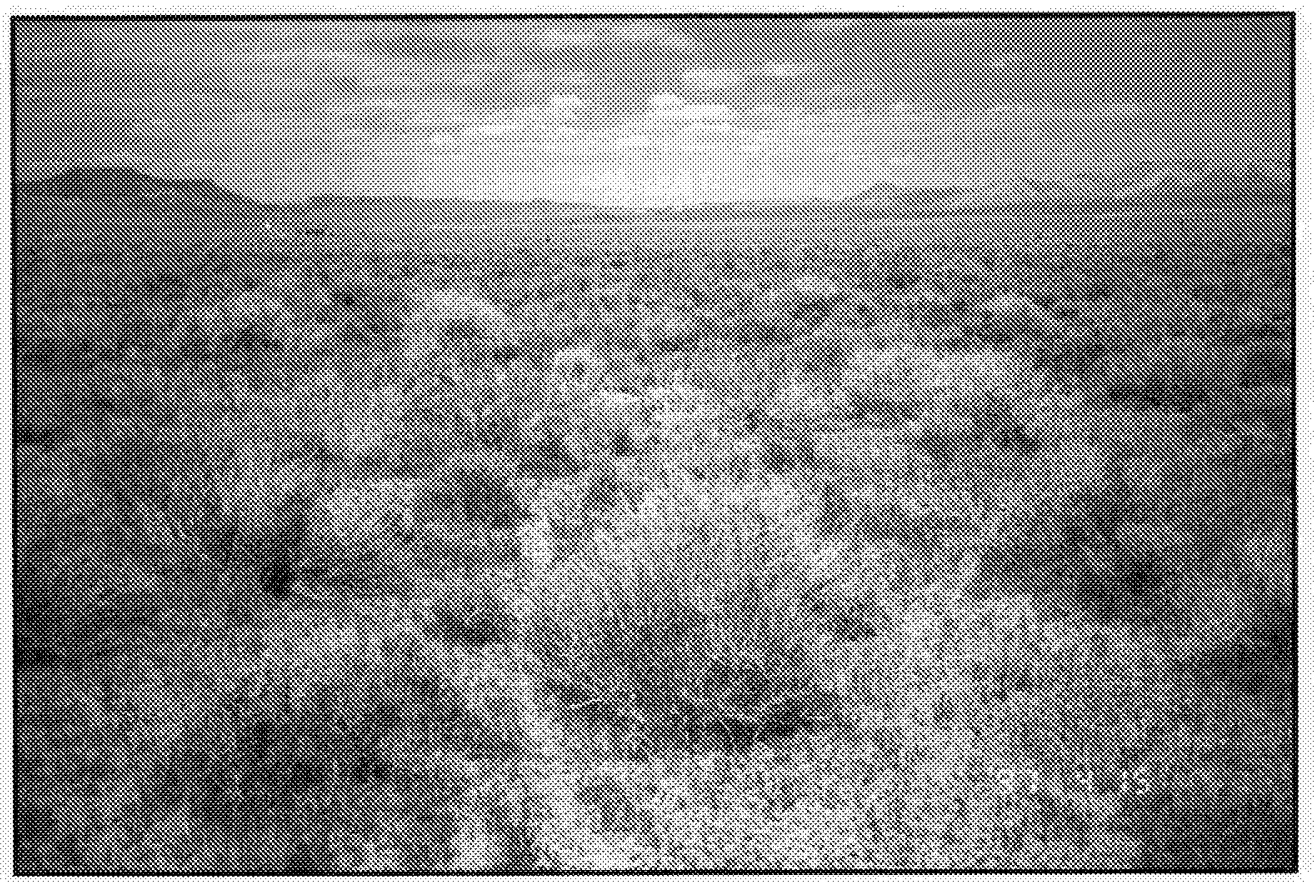

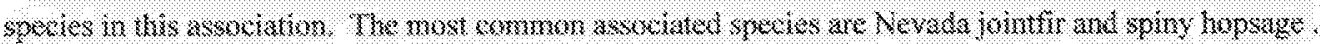

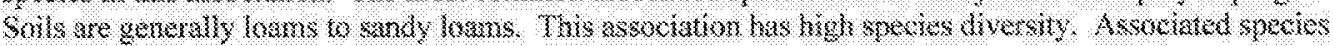

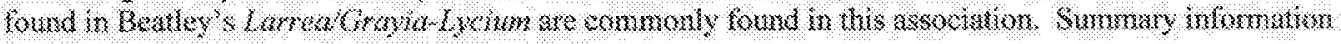

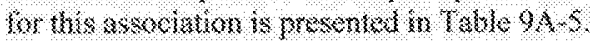

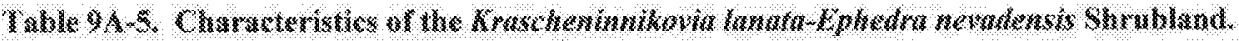

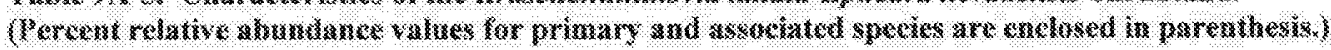

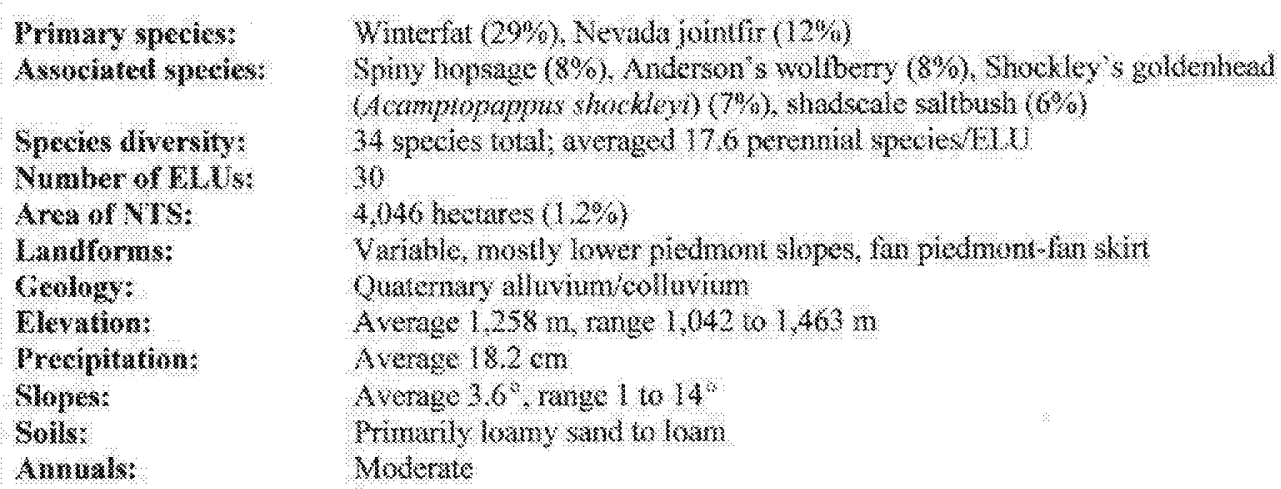

Kromaxyects:

Assuciateef species:

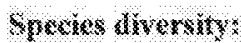

Number of $\mathrm{R}$.

Area of NIS:

Las atutorms:

Gerestoxy:

Elevariom:

Prexingtatinum:

Slogese:

Soils:

A

Watem

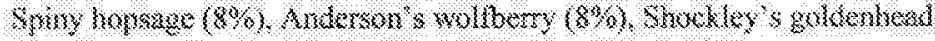

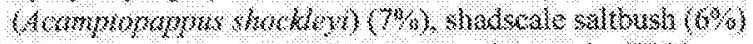

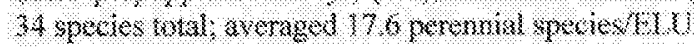

30

4946 kxwares $(1,2 \%)$

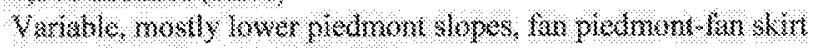

Quakemary alhwhmicolleviom

Average $1358 \mathrm{~m}$, range 1,642 o $4,463 \mathrm{~m}$

A verage $18.2 \mathrm{cts}$

Aremge $3.6^{\circ}$, ramge 1 to 44

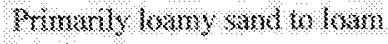

Mojlerate 


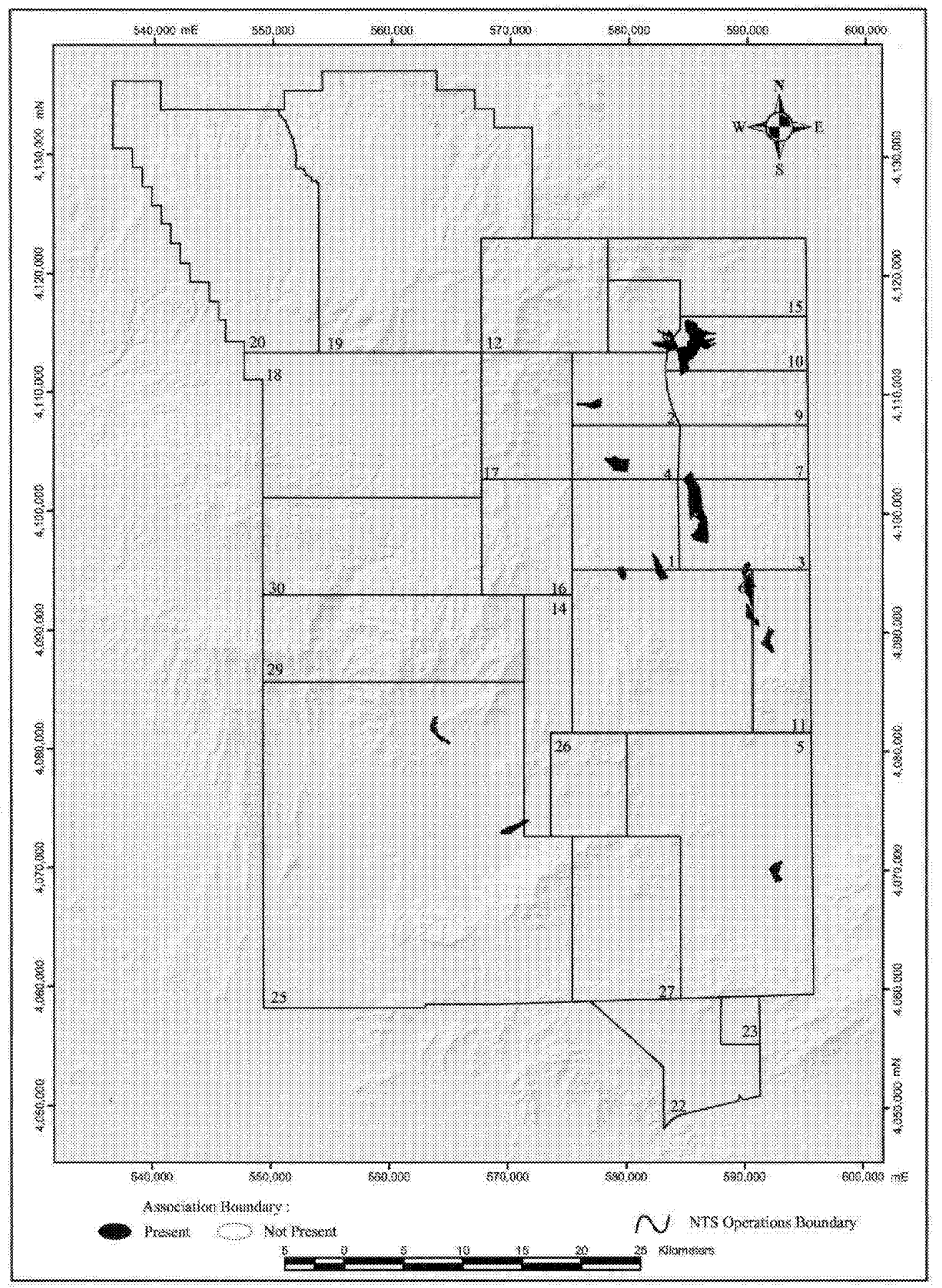

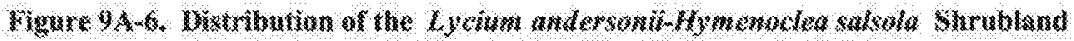

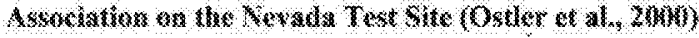




\section{A-6.0 Lycium andersonii-Hymenoclea salsola Shrubland}

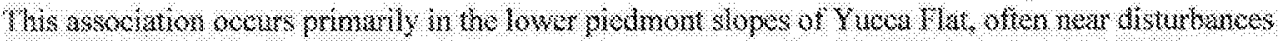

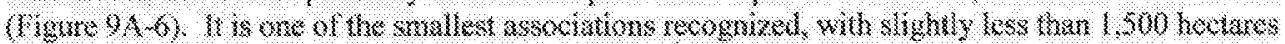

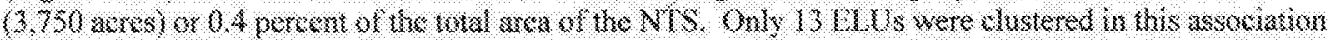

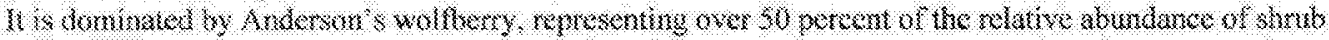

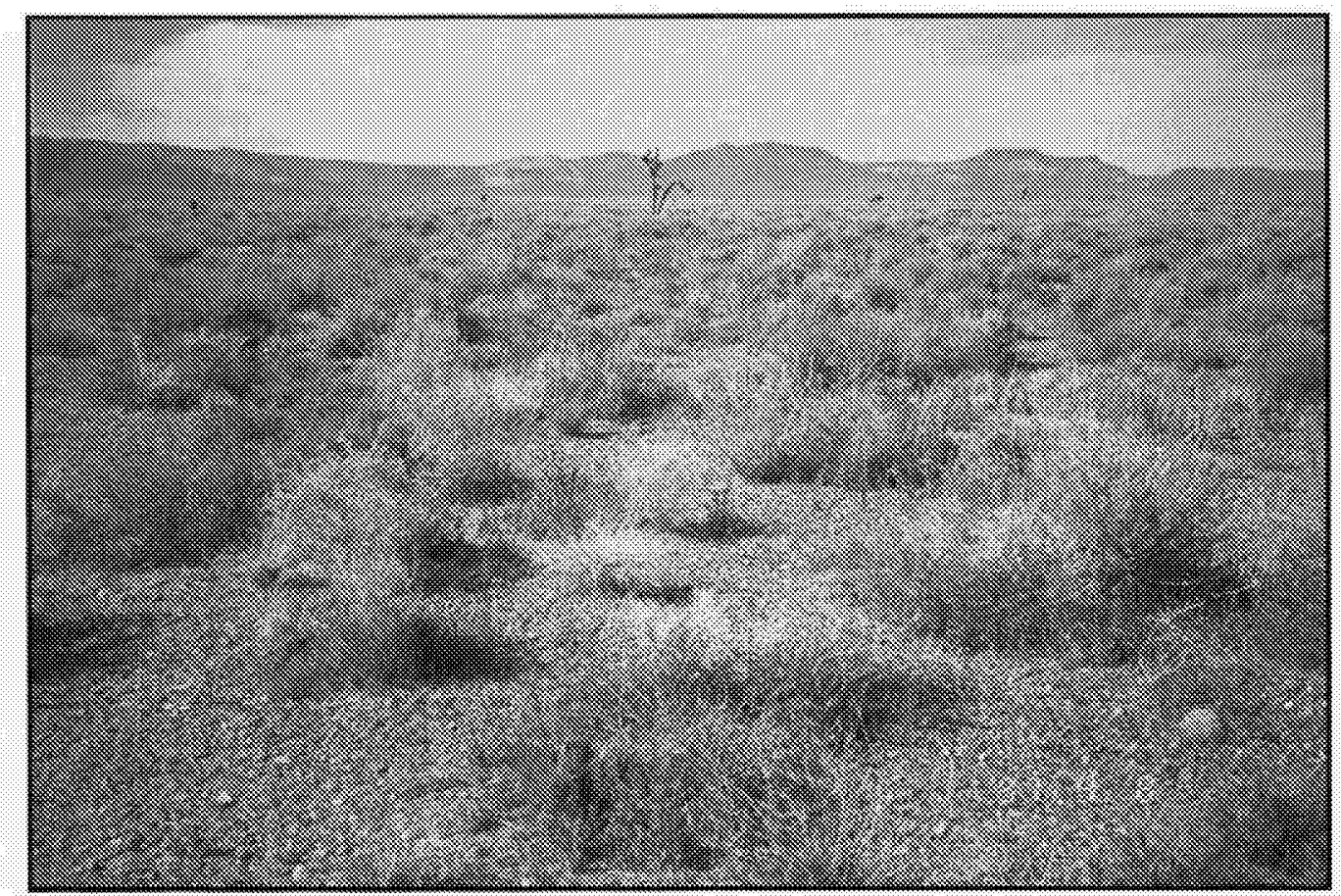

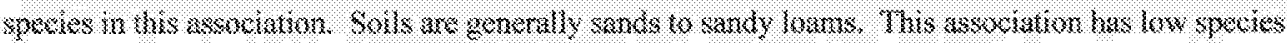

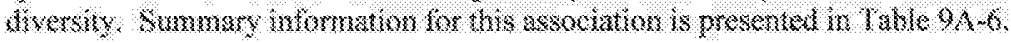

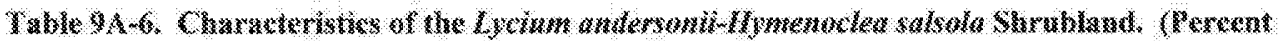
\%

Tratary spowas:

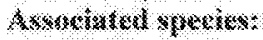
Species divervity:

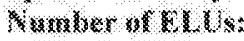
सres af NT:

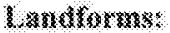

Coxistexy:

Wow

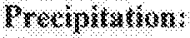

Swares:

Sortls:

A

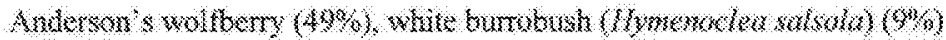

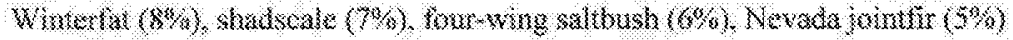

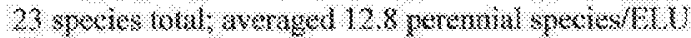
13

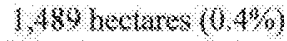

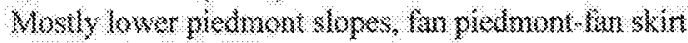

Ouaternary alliswiun

Average $1,263 \mathrm{~m}$, ange 942 ko $1,408 \mathrm{~m}$

Aversas $18.3 \mathrm{om}$

Avarase $23^{\circ}$, range 1 to $31^{\circ}$

Primarly sand bo sindy lowat

Modenite 60 very high 
THIS PAGE INTENTIONALLY LEFT BLANK 


\section{APPENDIX 9B}

\section{Root Observations in Pit 8 at Area 5 RWMS}

Excavation of Disposal Pit 8 at the Area 5 RWMS began in early August of 2001. The vegetation at this location had previously been described (in this report) and characterized by Bechtel Nevada biologists. This area was referred to as Site 1 and is located about 600 meters $(\mathrm{m})$ north of the existing Disposal Pits 1-7. The excavation provided an opportunity to observe the roots of relatively undisturbed vegetation present at the site. Construction activities were designed to enhance observations by providing a steep (nearly vertical) cut wall to expose roots. Excavation was halted periodically so that observations and field measurements could be made. The following information was collected at that time on a limited number of plants that were located along the high wall. A description of each day's observations follows together with tables describing key features (Appendix Table 9A1 and 9A2).

\section{August 9, 2001-Thursday}

- BN biologists harvested above-ground biomass from 15 creosote bushes (Larrea tridentata) growing along the western edge of the pit. These shrubs were growing approximately in center of the pit length about 35 meters $(\mathrm{m})$ [115 feet $(\mathrm{ft})]$ from the southern edge and about 3 to $6.1 \mathrm{~m}(10$ to $20 \mathrm{ft})$ in from the surveyed edge of the pit.

\section{August 11, 2001-Saturday}

- Excavation was made using a scraper to remove soil and dig up plants. BN biologists harvested roots from nine plants along the excavation face. Biologists were unable to harvest 100 percent of the roots because small fragments were lost during excavation. Root biomass was air dried. The percentage of small root fragments not harvested is not known, but probably ranges from 5 to 15 percent, consistent with prior reports by other biologists of unrecoverable plant roots collected during excavation (Wallace et al., 1974).

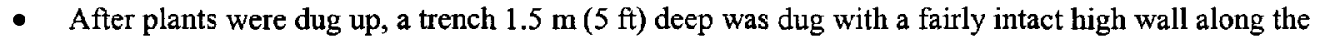
eastern (west-facing) edge. The western edge (east facing) sloughed off.

- Observations were made on root abundance and types at different depths and are reported in the Appendix Table 9A1.

- Roots were observed down to about $1.5 \mathrm{~m}(5 \mathrm{ft})$, which was the depth of the trench. There appeared to be a "lens" of soil that prohibited root penetration. The "lens" appeared similar to caliche or hardpan, but was not near as hard or compacted as typical hardpan. It was not possible to tell if root restrictions were due entirely to the hardpan, because the lens was at about the $1.5-\mathrm{m}(5-\mathrm{ft})$ level-the level of the trench at that point in time. The largest roots were near the surface, probably within 91 centimeters $(\mathrm{cm})(3 \mathrm{ft})$ of the surface; many of the roots went laterally within $61 \mathrm{~cm}(2 \mathrm{ft})$ of surface. At the $1.5-\mathrm{m}$ (5-ft) level were root hairs and an occasional root of (1 to 2 millimeters (mm) [1/32 to $1 / 16$ inch (in)] in diameter. Most of the root hairs seemed to stop at the depth where the soil was compacted, at around $1.5 \mathrm{~m}(5 \mathrm{ft})$.

\section{August 22, 2001-Wednesday}

- Excavation was down approximately $3 \mathrm{~m}(10 \mathrm{ft})$ on the western edge of Pit 8 .

- Measurements were made on rooting depth along the western edge of the pit, with a few observations made on the eastern edge of the pit.

- Observations that were made at the $1.5-\mathrm{m}(5-\mathrm{ft})$ level were about the same as at $3-\mathrm{m}(10-\mathrm{ft})$ level. The majority of roots, especially larger diameter roots, were within 61 to $91 \mathrm{~cm}$ (2 to 3 feet) of soil surface. However, some roots were observed at deeper levels. At the $3-\mathrm{m}(10-\mathrm{ft})$ level, root hairs were still observed, about the same size and diameter as at the $1.5-\mathrm{m}(5-\mathrm{ft})$ level. Root hairs were very brittle and observable only after lightly touching the soil profile with a whisk broom. It was not possible to tell if the root hairs went below $3 \mathrm{~m}$ (10 ft). Small vertical trenches exposing about 61 to $91 \mathrm{~cm}(2$ to $3 \mathrm{ft}$ ) of the soil profile were dug along the western edge. 


\section{August 29, 2001-Wednesday}

- Excavation was down to about 5.5 to $6.1 \mathrm{~m}$ (18 to $20 \mathrm{ft}$ ).

- Observations were made primarily along the western edge. Along the eastern edge, root hairs were observed over $3 \mathrm{~m}$ (10 ft) down, probably between 3.7 to $4.6 \mathrm{~m}$ (12 and $15 \mathrm{ft})$. A vertical trench was used to expose the root hairs. They were observed infrequently down to the $3.7-\mathrm{m}$ to $4.6-\mathrm{m}$ (12-ft to $15-\mathrm{ft})$ level. No roots were observed below the $4.6-\mathrm{m}(15-\mathrm{ft})$ level. The soil became quite coarse and gravelly, but no root hairs were observed. Above the $3.7-\mathrm{m}(12-\mathrm{ft})$ level, the soil still had a fair amount of fine soil particles in which root hairs were found.

\section{December 5, 2001-Wednesday}

- Air-dried root and shoot biomass were weighed; the weights are reported in Table 9A2.

\section{Results}

Total mean living volume measured for creosote bush was 2 cubic meters $\left(\mathrm{m}^{3}\right)\left(70.6 \mathrm{ft}^{3}\right)$ (Appendix Table 9A2). This value compared favorably with measurements reported for creosote bush $\left(2.37 \mathrm{~m}^{3}\right)\left(83.7 \mathrm{ft}^{3}\right)$ by Wallace et al., 1974.

The mean root-to-shoot ratio for creosote bush was 1.26 (root weight/shoot weight) which compared favorably with measurements reported for creosote bush (1.24) by Wallace et al., 1974.

Root depth for the eight shrubs occurring along the high wall did not exceed $1.5 \mathrm{~m}(5 \mathrm{ft})$ in depth, although individual root hairs (apparently not directly traceable to the eight sample plants observed) were observed at depths down to $4.6 \mathrm{~m}(15 \mathrm{ft})$. Most creosote bush roots were concentrated in the top two meters of soil where mean precipitation amounts most frequently provide moisture. Small root hairs or small roots were observed infrequently at depths greater than $1.5 \mathrm{~m}$ ( $5 \mathrm{ft}$ ). Roots at these greater depths probably grow to such depths only during years that experience greater than normal precipitation or where water from precipitation finds rodent or insect tunnels that may direct water deeper. 


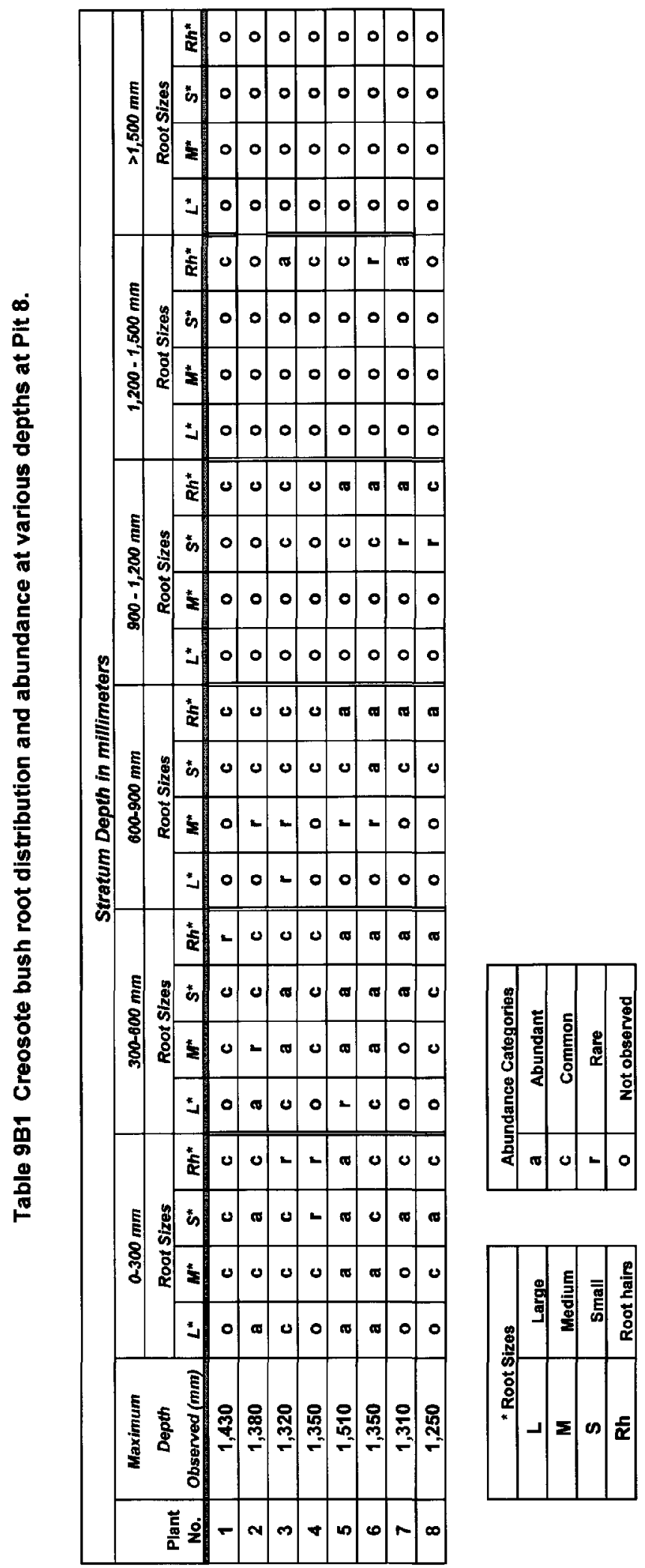



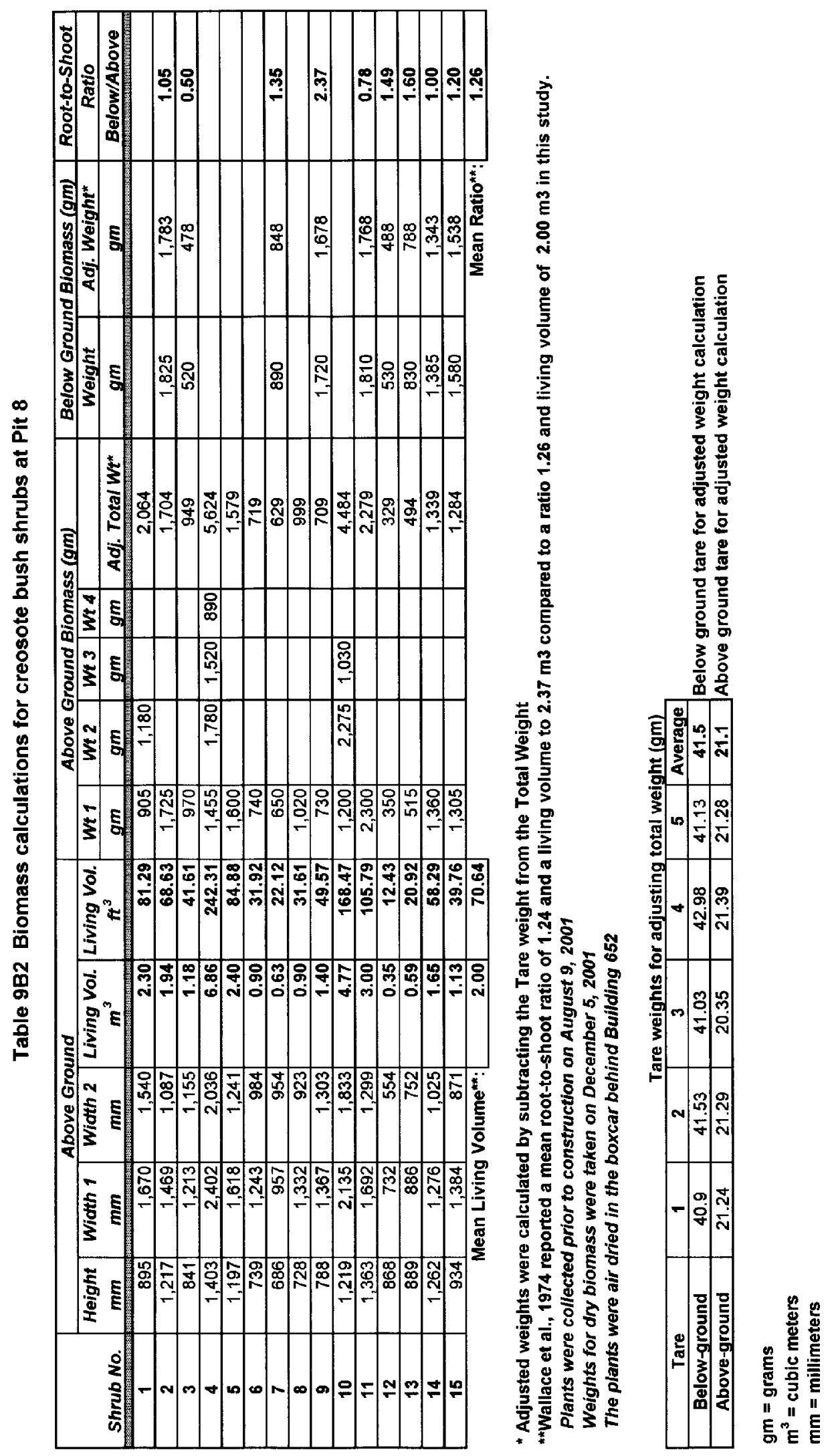


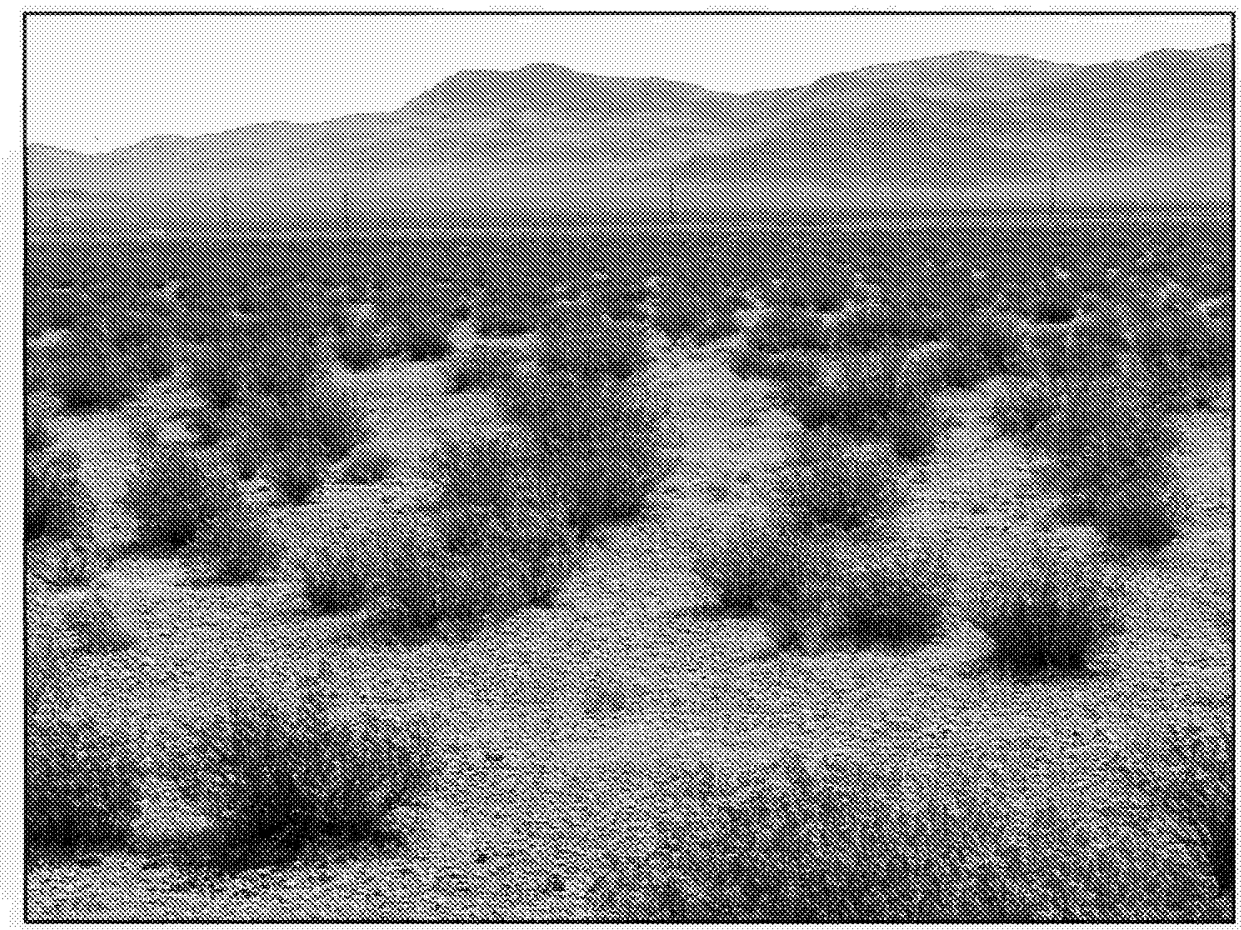

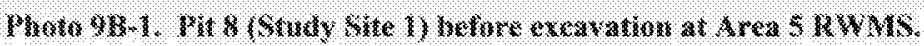

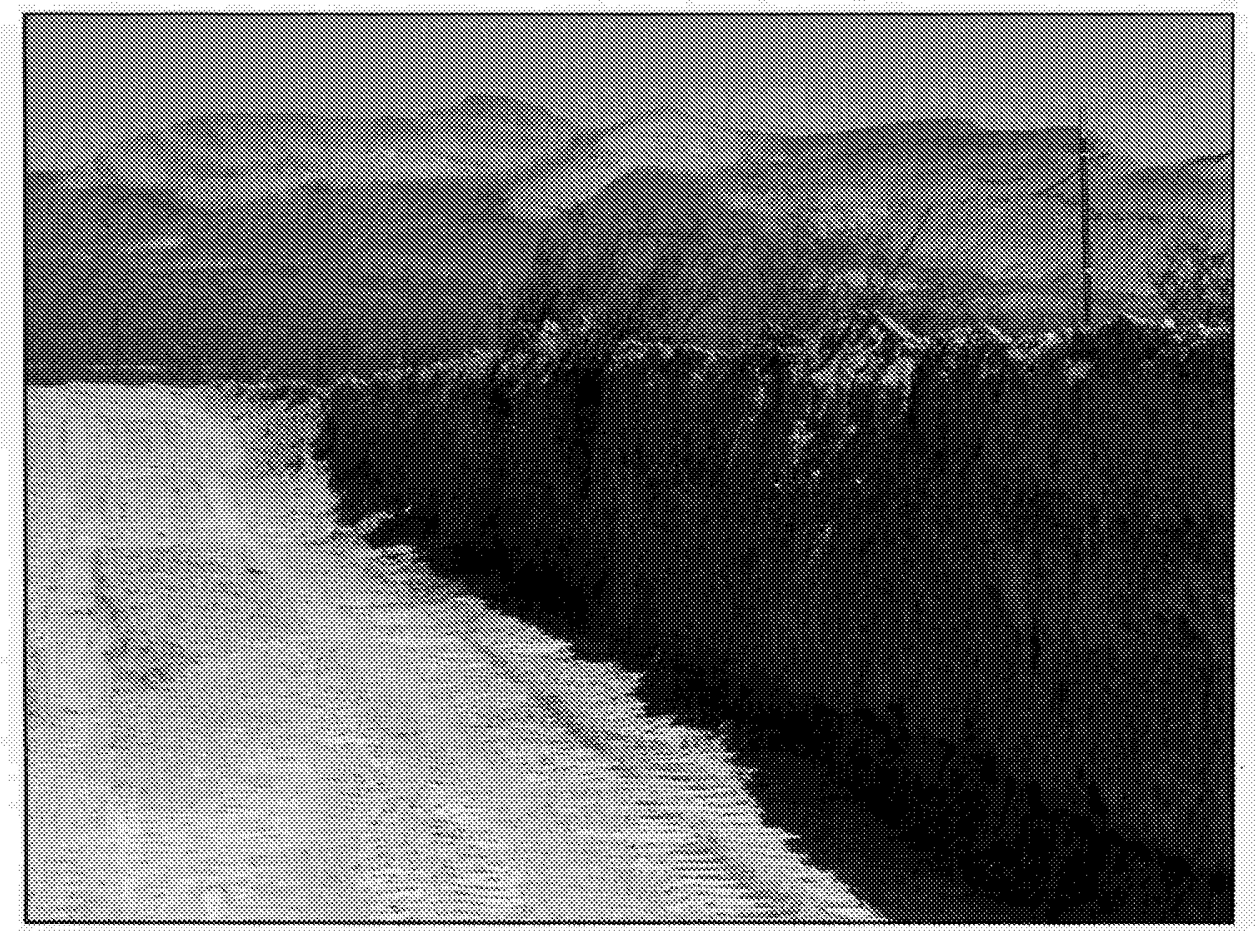

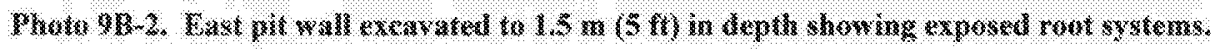




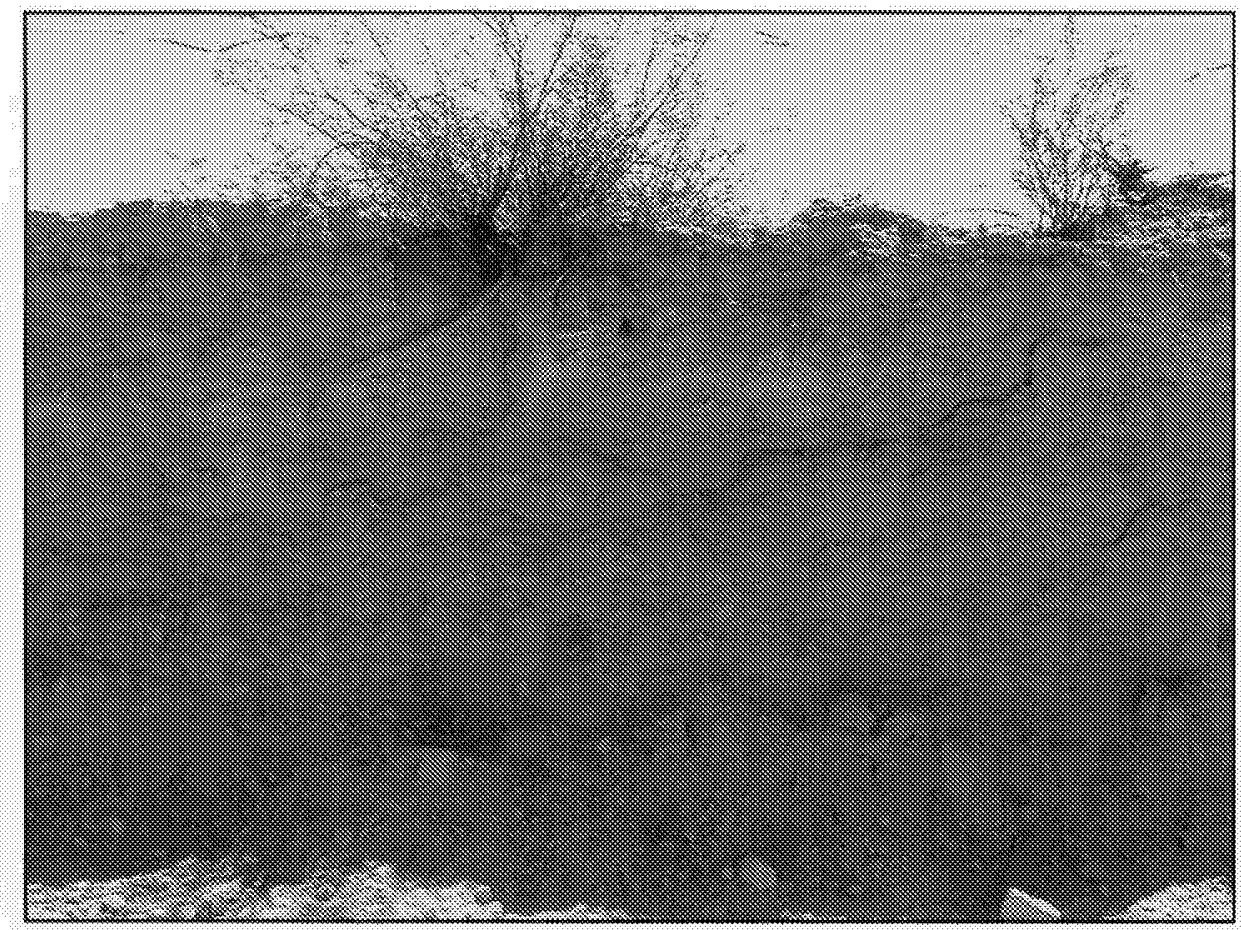

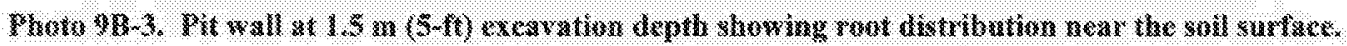

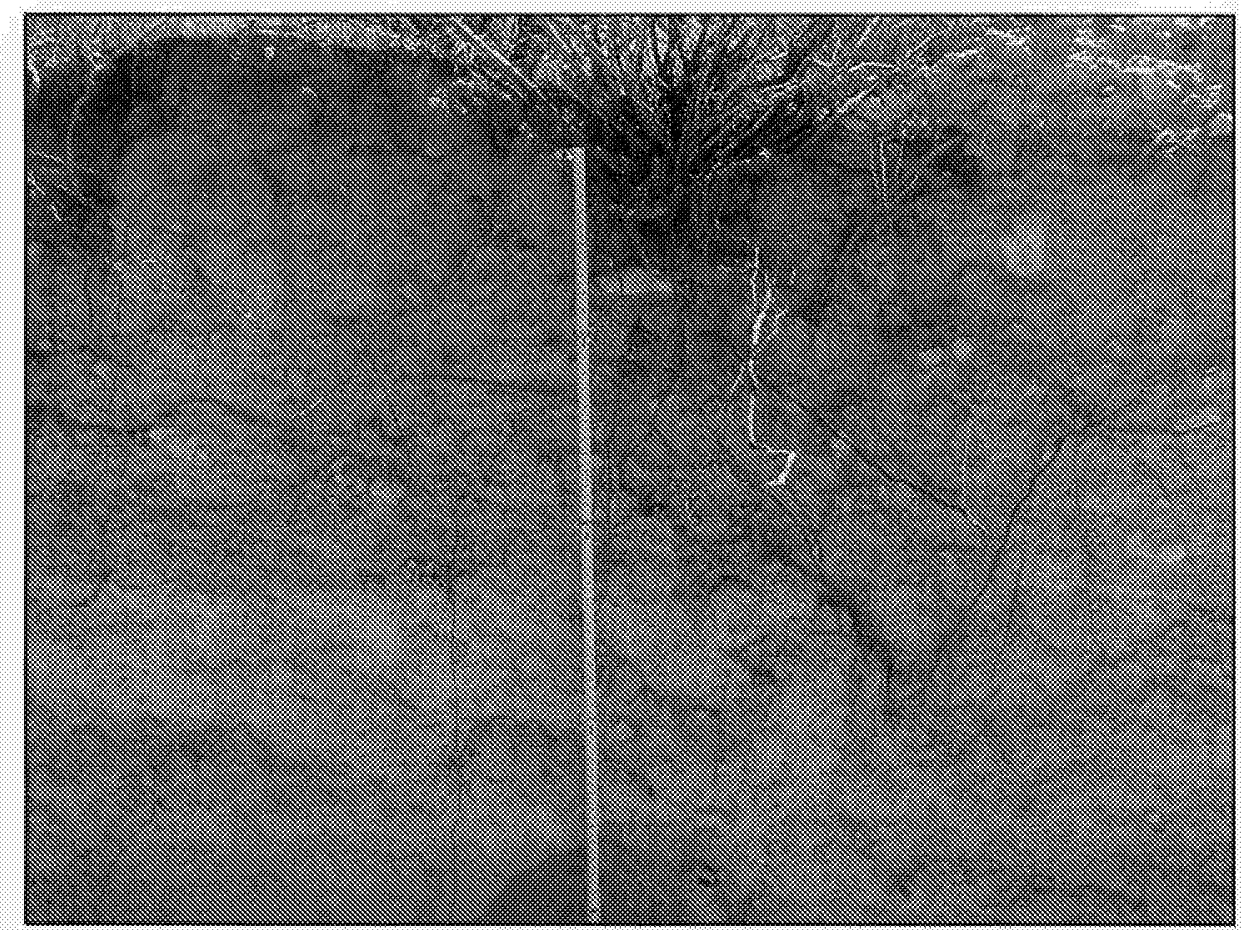

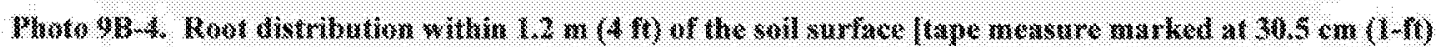
intersaluy. 


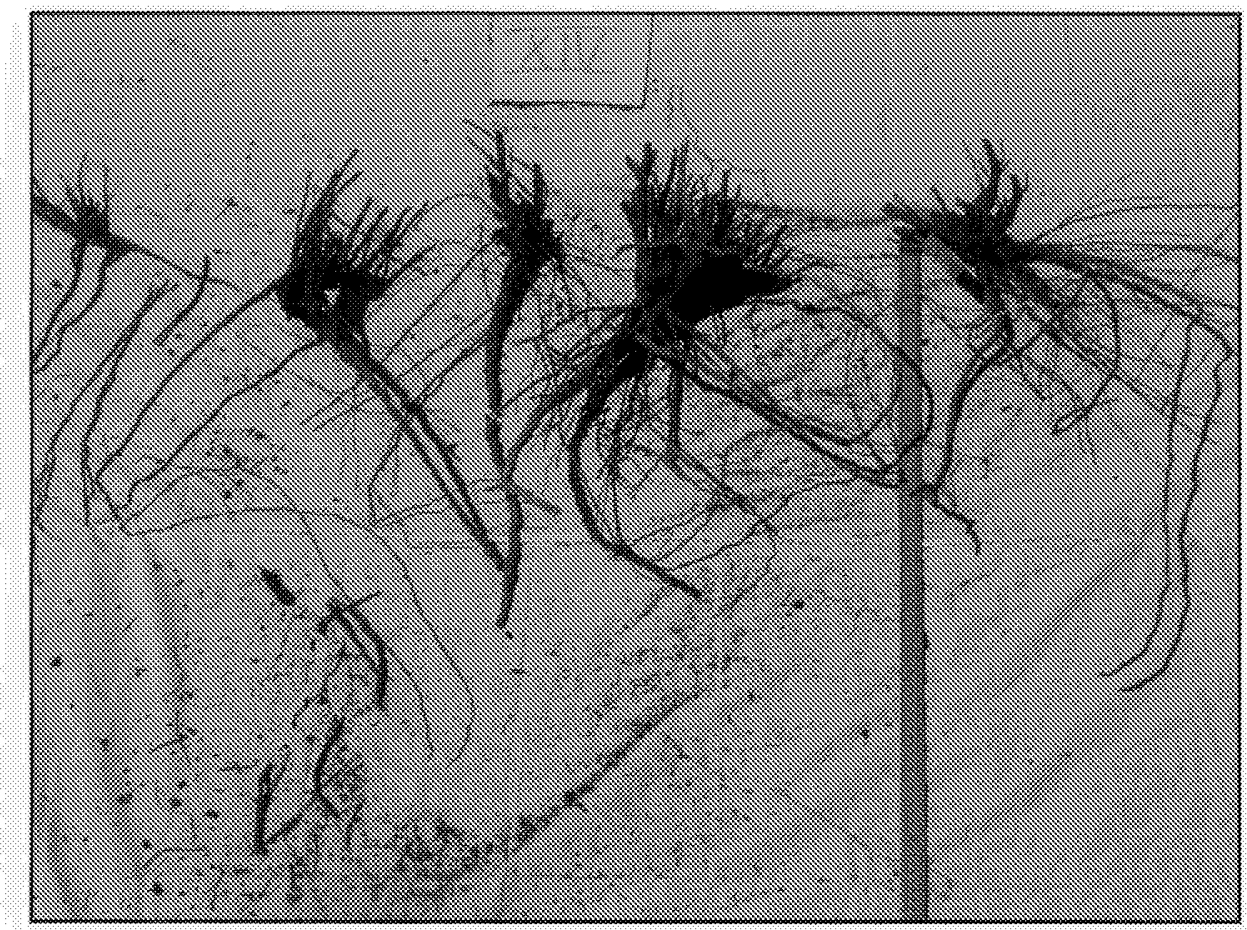

Photo 98-5. Nxeswated rowts showing branching patkerss gear the soil surface. Nont mass was used to

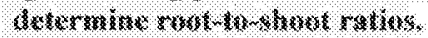

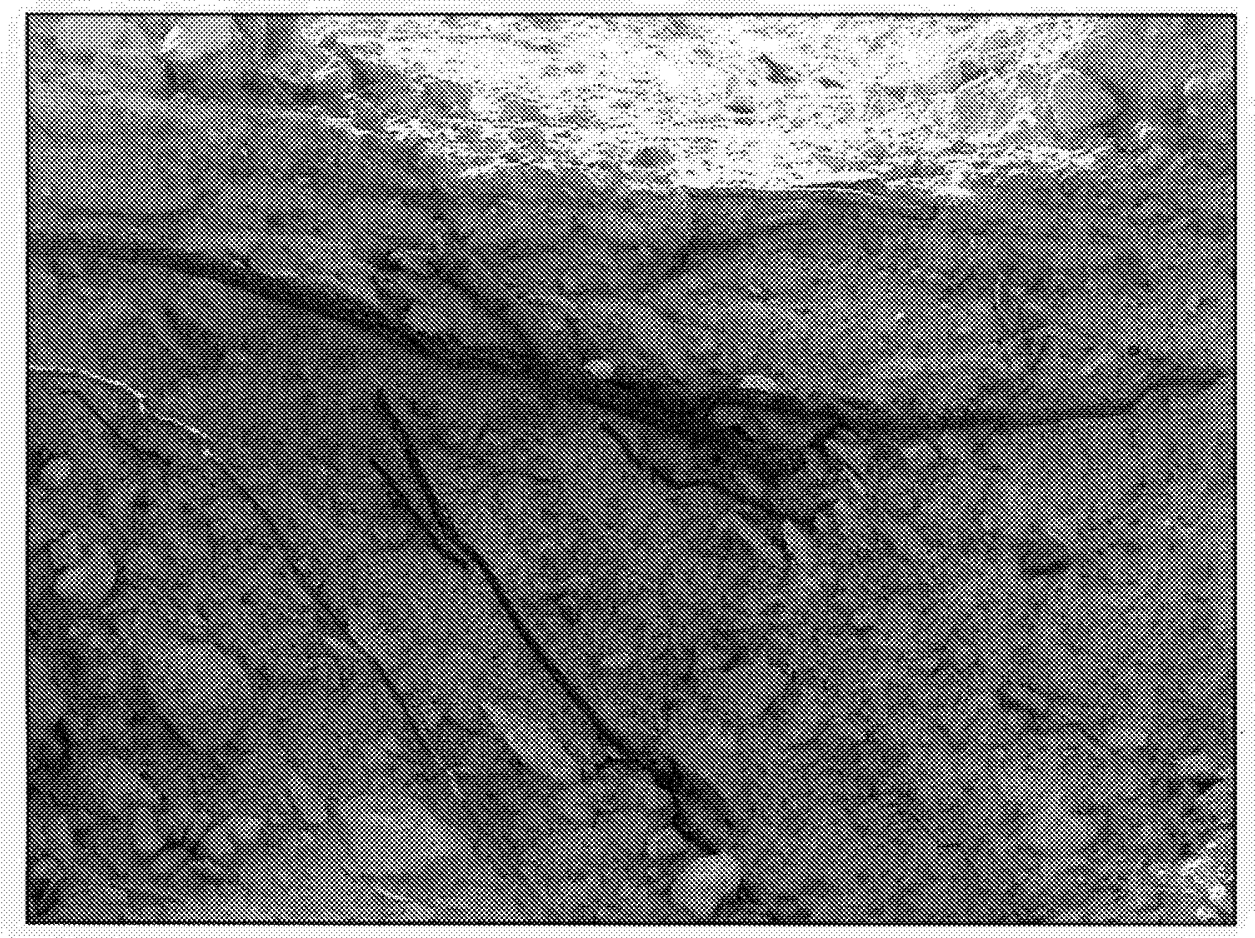

Photes 98-6. Roots exeending kerizontally front shruh crown near the swil surface. 


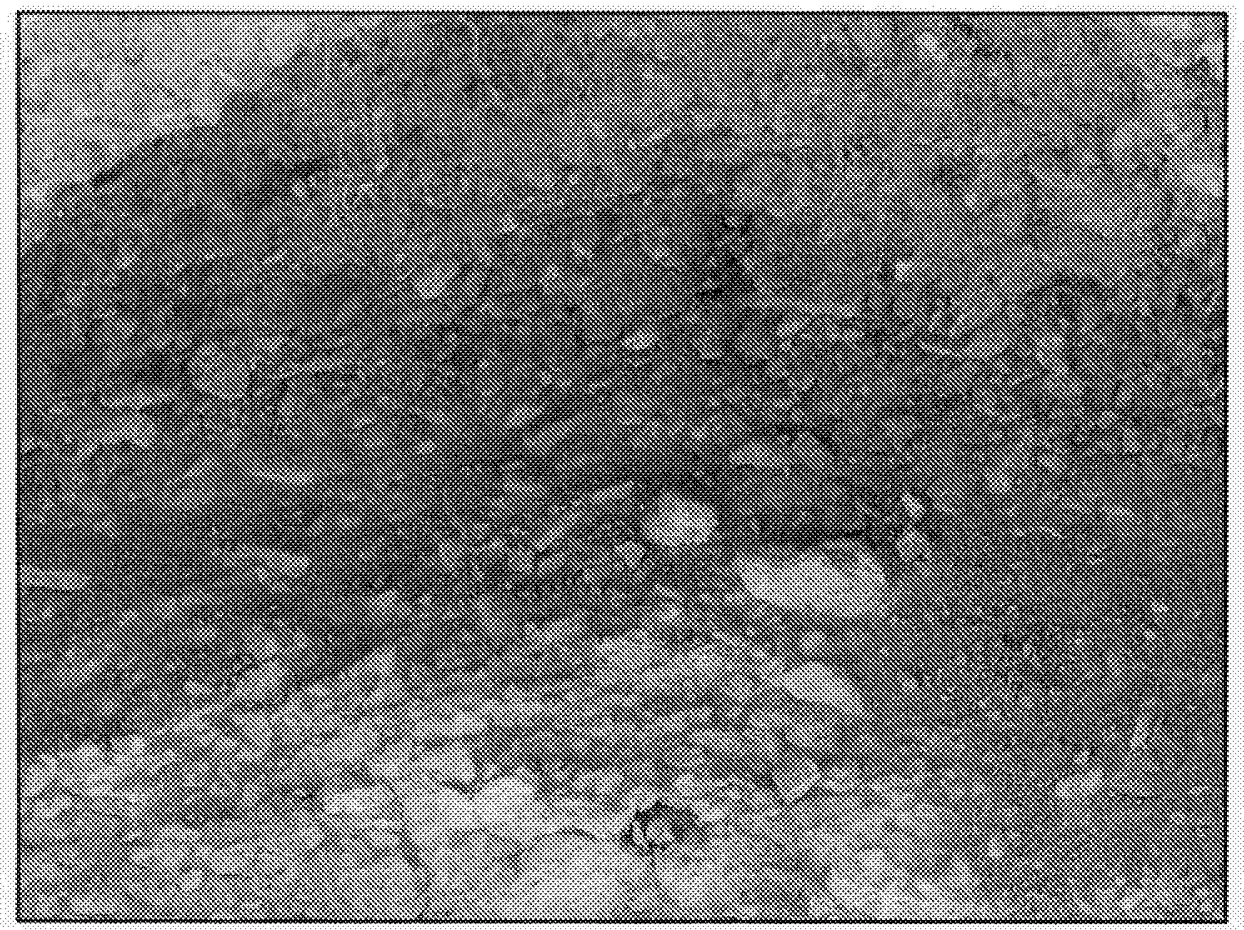

Whoto 9g-7. Abundunt small root hairs above a white, hard-pan layer at the bokton af the photo 1 , sm (5 II).

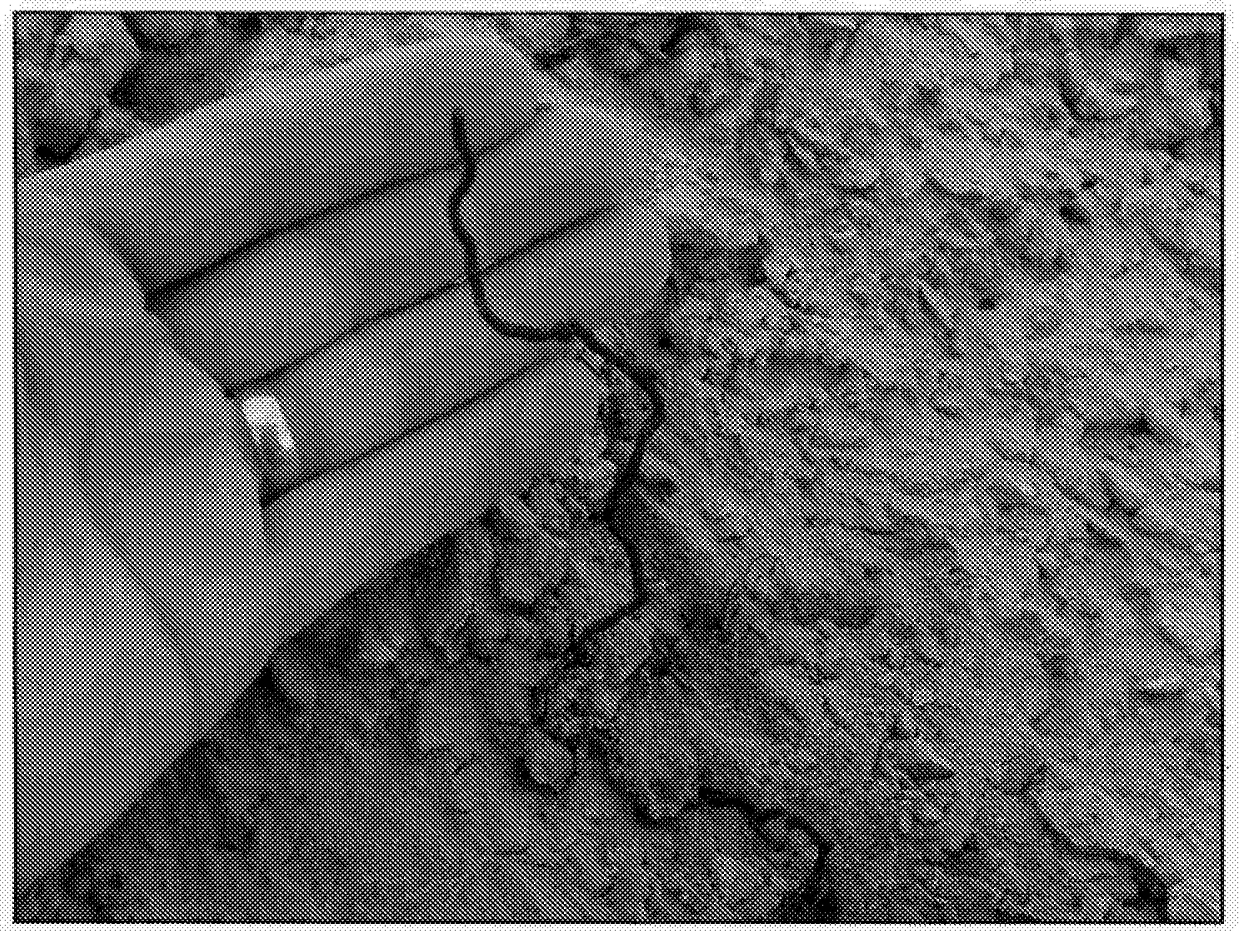

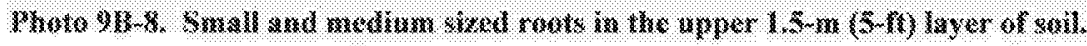




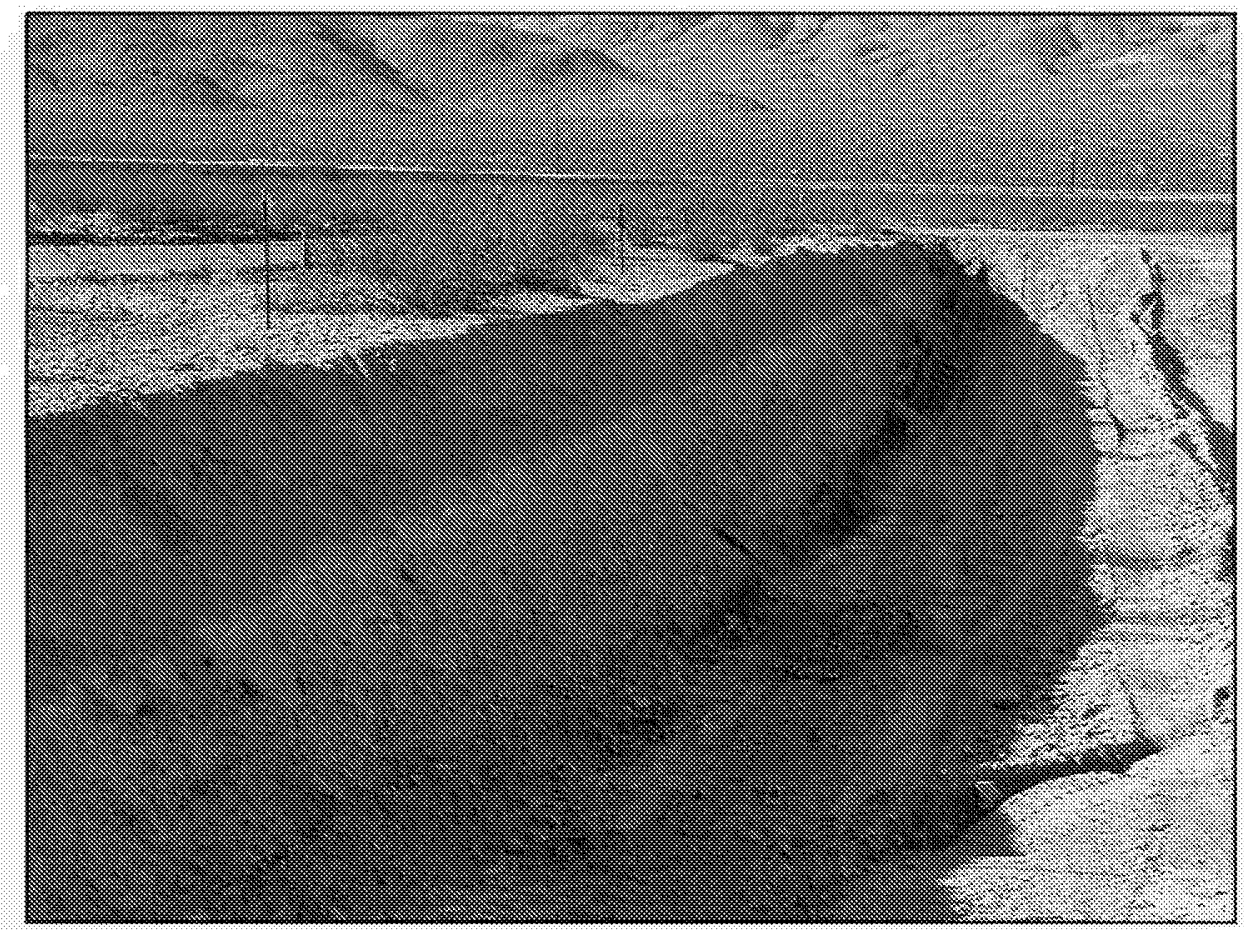

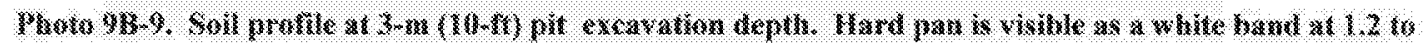
$4.5 \mathrm{~m}(4,65$ leti) theth.

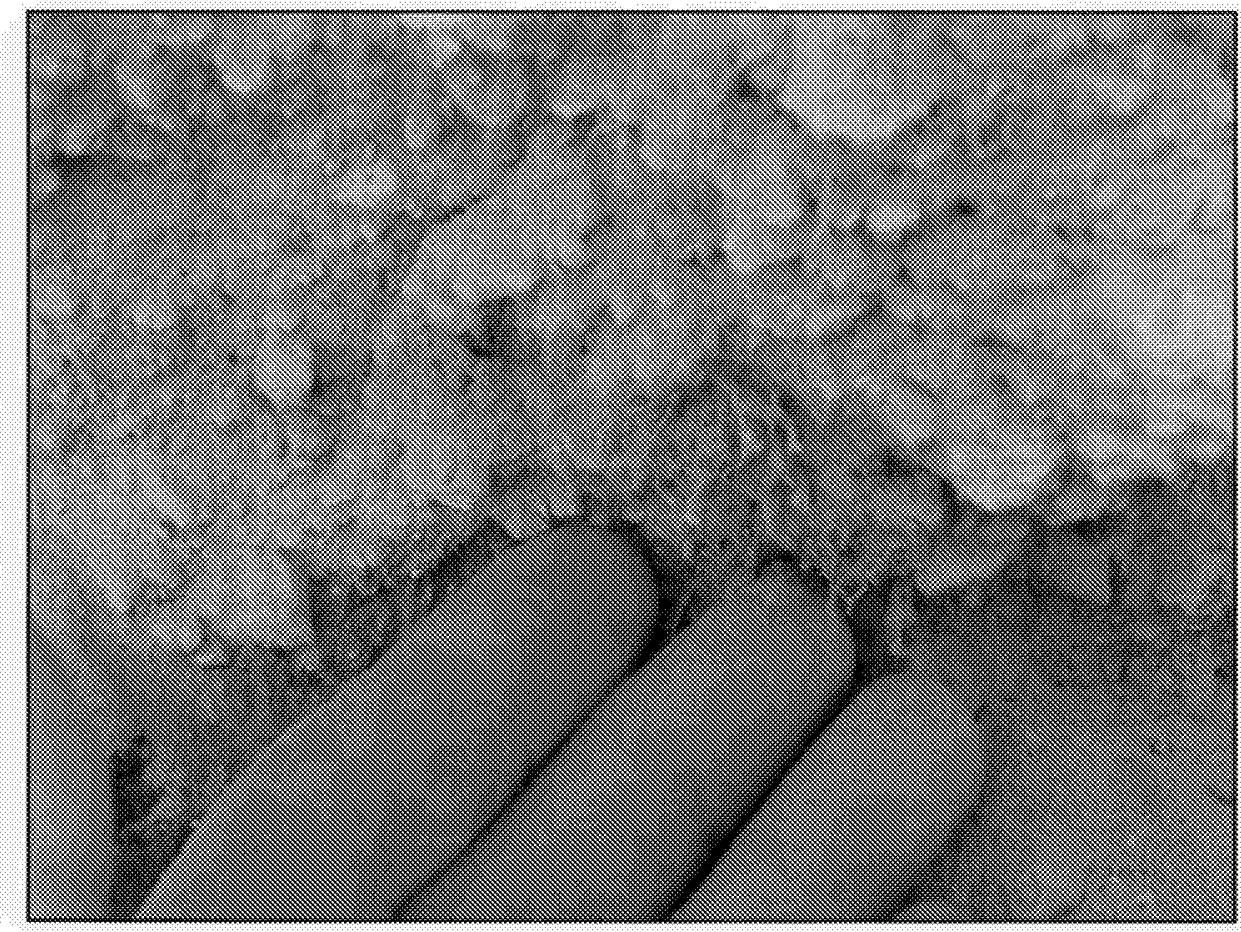

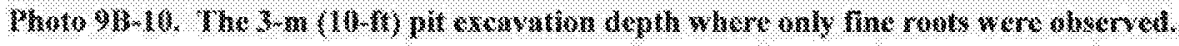




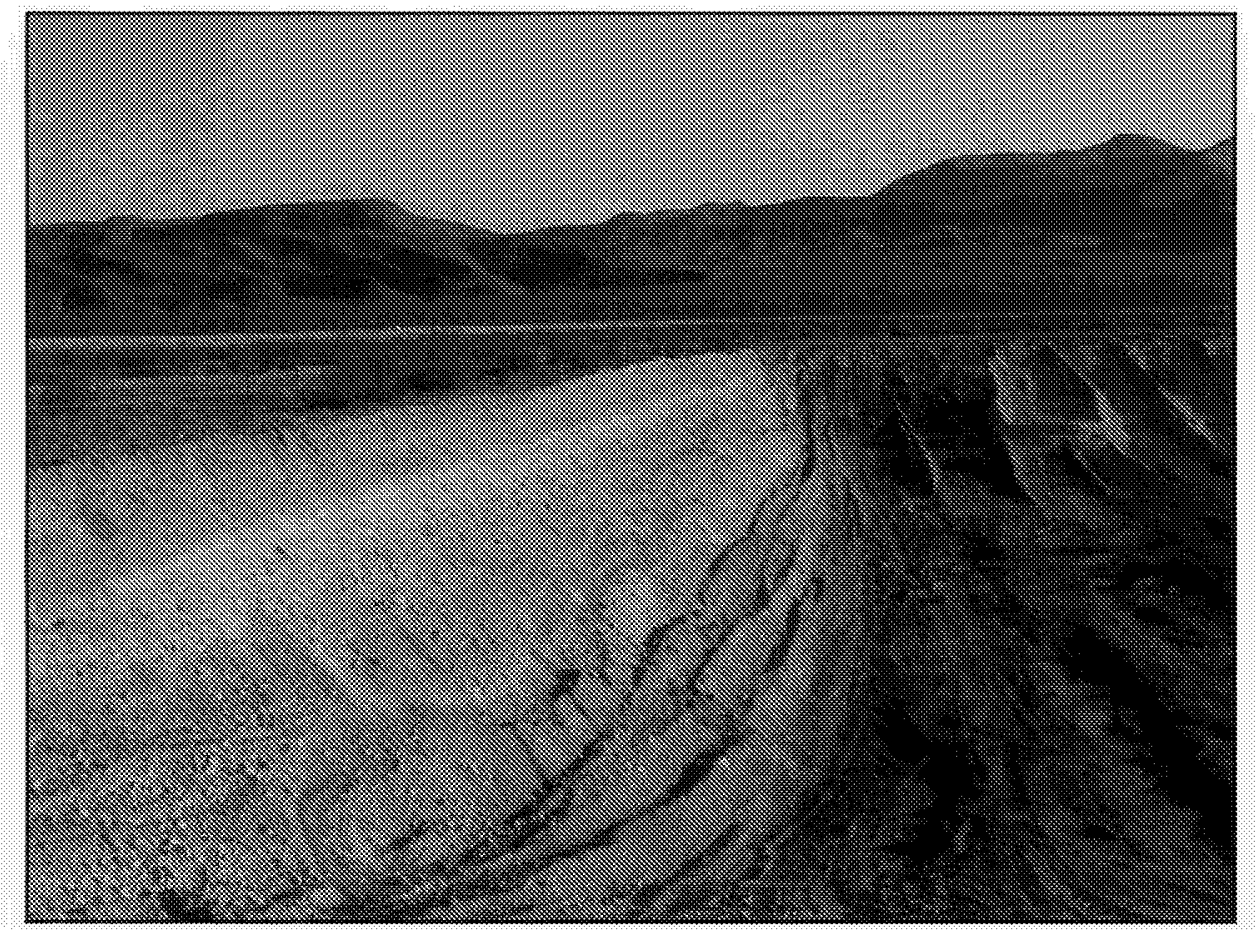

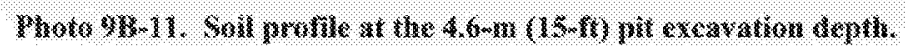

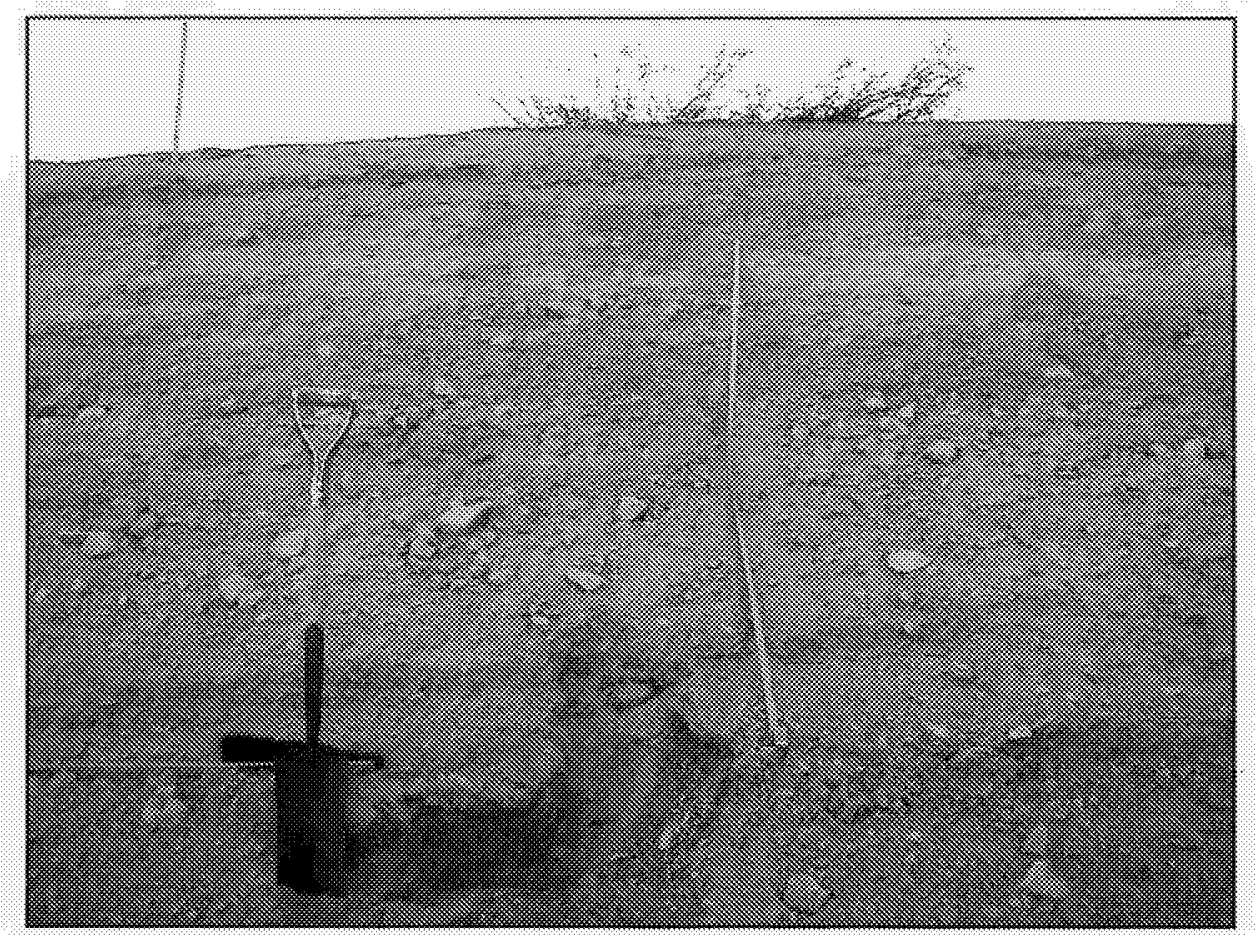

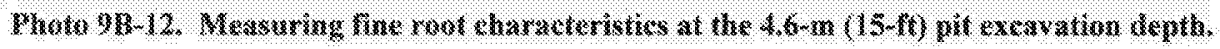




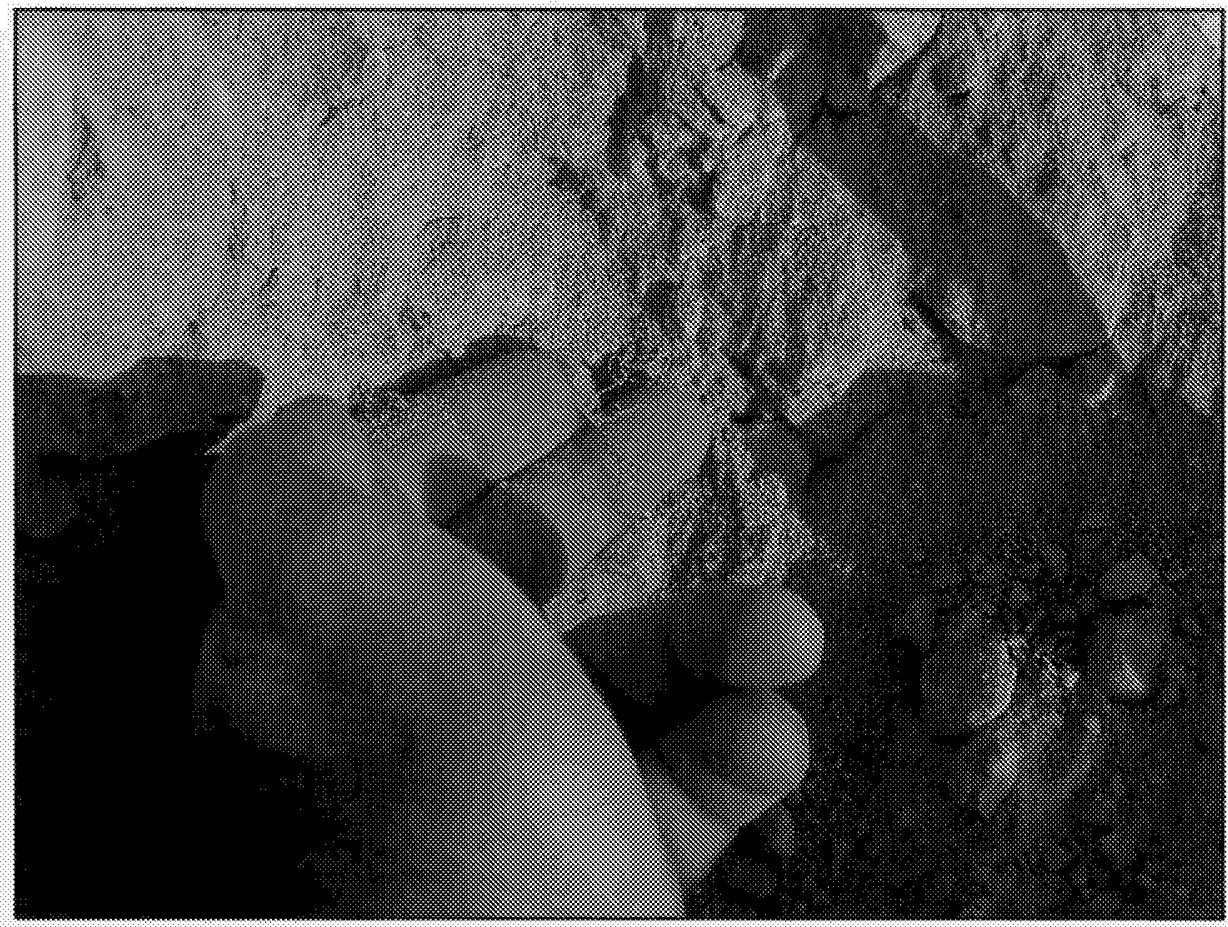

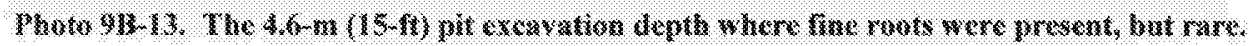

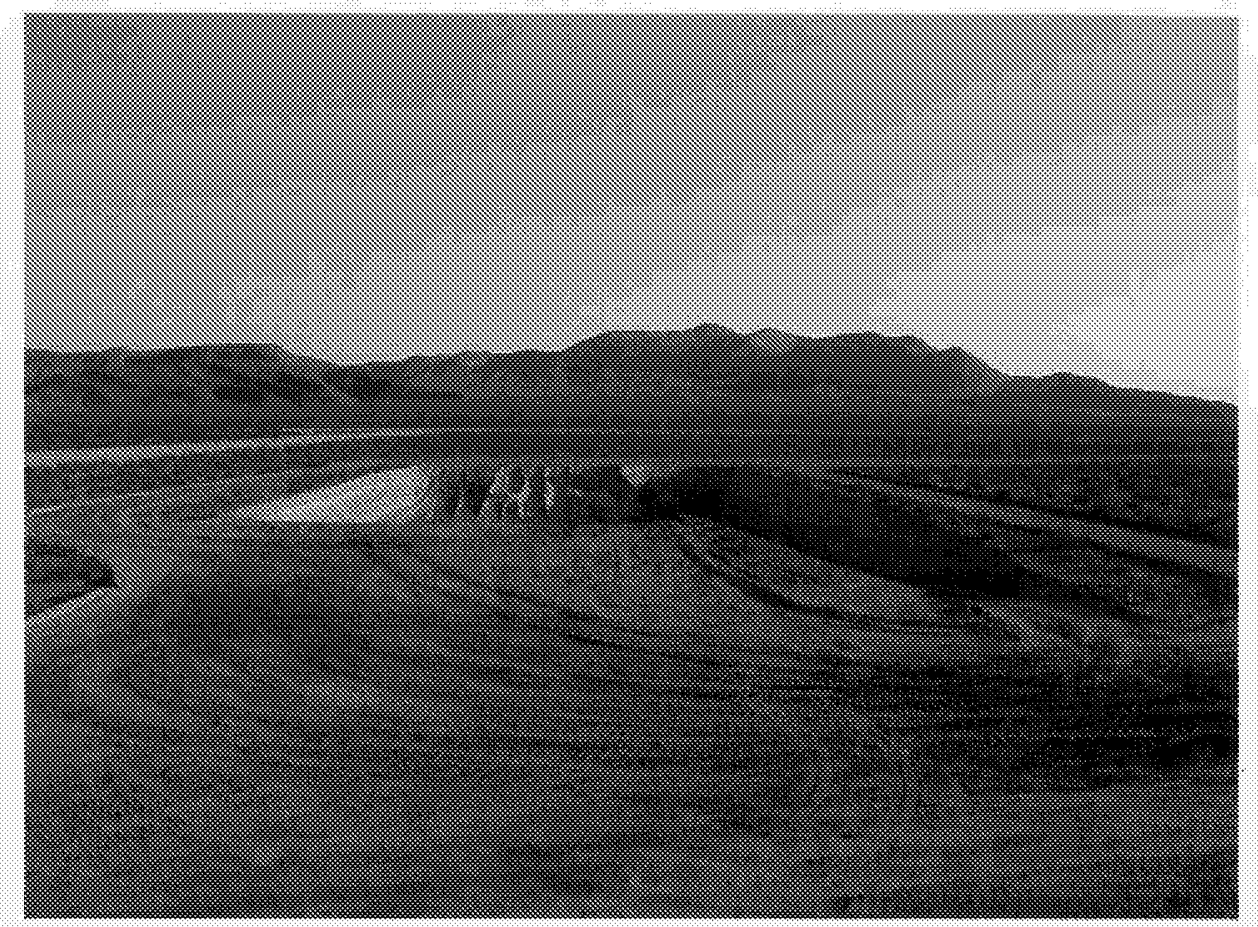

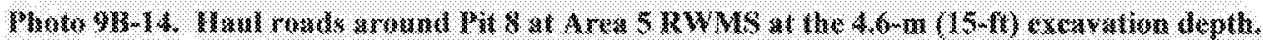

